\title{
Characterization of Technological Innovations in Photovoltaic Rural Electrification, Based on the Experiences of Bolivia, Peru, and Argentina: Third Generation Solar Home Systems
}

\author{
Miguel H. Fernandez-Fuentes ${ }^{1,2, * \mathbb{C}}$, Andrea A. Eras-Almeida ${ }^{1} \mathbb{D}$ and Miguel A. Egido-Aguilera ${ }^{1} \mathbb{D}$ \\ 1 Instituto de Energía Solar, ETSI Telecomunicación, Universidad Politécnica de Madrid, 28040 Madrid, Spain; \\ andrea.eras@ies.upm.es (A.A.E.-A.); egido@ies.upm.es (M.A.E.-A.) \\ 2 ENERGETICA Foundation, La Paz, Cochabamba E-573, Bolivia \\ * Correspondence: miguel@energetica.org.bo; Tel.: +591-71-735-123
}

\section{check for}

updates

Citation: Fernandez-Fuentes, M.H.; Eras-Almeida, A.A.; Egido-Aguilera, M.A. Characterization of

Technological Innovations in

Photovoltaic Rural Electrification,

Based on the Experiences of Bolivia,

Peru, and Argentina: Third

Generation Solar Home Systems.

Sustainability 2021, 13, 3032.

https://doi.org/10.3390/su13063032

Academic Editor: Aritra Ghosh

Received: 7 February 2021

Accepted: 3 March 2021

Published: 10 March 2021

Publisher's Note: MDPI stays neutral with regard to jurisdictional claims in published maps and institutional affiliations.

Copyright: (c) 2021 by the authors. Licensee MDPI, Basel, Switzerland. This article is an open access article distributed under the terms and conditions of the Creative Commons Attribution (CC BY) license (https:// creativecommons.org/licenses/by/ $4.0 /)$.

\begin{abstract}
The electrification of isolated homes in rural areas without access to the electric grid has been achieved in part using solar energy transformed into electricity through Photovoltaic (PV) equipment known as Solar Home Systems (SHSs), which has been widely disseminated throughout the world. The use of SHSs in rural electrification projects has been studied from 1980 to date, they have been incorporating advances and technological innovations successively. Through the review of documents on PV projects, articles, and technical reports, it has been possible to identify the changes in the main components of the SHS and the typical configurations, systematizing them in a discrete timeline. Thereby, this article characterizes three generations of SHSs and highlights their differences. The first generation is fully valid between 1980-1995, the second generation in 1995-2010, and the third generation from 2005 to date, which overlaps the beginning. In any case, the time limits in each period are only referential. The later generation, Third Generation Solar Home Systems (3G-SHSs), is highly efficient, uses LED lamps, lithium batteries, microelectronic control, and plug and play connections. Indeed, this equipment can be self-managed by the user and reflects the technology's high reliability by a minimum maintenance service in situ. Furthermore, their lower costs make access to electricity more affordable for the last mile population. The present research offers a detailed technological and operational characterization of the 3G-SHSs to show the most relevant aspects of support to project developers, planners, and decision-makers to achieve the Sustainable Development Goal (SDG) 7.
\end{abstract}

Keywords: universal access to energy; off-grid electrification; third generation solar home systems; rural electrification

\section{Introduction}

The 17 Sustainable Development Goals (SDGs), agreed by the United Nations Conference at the Paris 2015 meeting, mark the international commitments to eradicate poverty and improve people's quality of life [1]. Objective number seven, SDG 7, determines that by 2030 all the planet inhabitants should have clean, modern, and safe energy services. Energy is essential to improve the quality of life of the population, generate synergies, and promote social, economic, health, education, and environmental achievements [2-5]. However, having a connection to the electricity grid does not automatically imply access to quality, reliable, safe and economical energy in line with the achievement of SDG 7. Ayaburi et al. (2020) estimated that 3.5 billion people have an electrical connection but suffer frequent and long-term interruptions, which would qualify the electrical service as unreliable and of low quality [6]. In practice, this population does not meet the conditions required by SDG 7. In this sense, ensuring access to energy implies more than a physical connection to an energy source, it also implies a quality supply. In particular, the lack of access to electric power in 2019 affected 10\% of the world population (771 million people) [7] who have affected 
their development possibilities [8]. The majority of this population is located in rural areas, especially in sub-Saharan Africa (578 million people without access to electricity), India, regions of Asia, and to a lesser extent, the Middle East and North Africa (see Figure 1). For the Latin America and the Caribbean (LAC) region, the electricity coverage has increased to $98.31 \%$, considering it one of the regions with the highest electrical coverage on the planet. However, there are still 11 million people without access to electricity in this region [9].

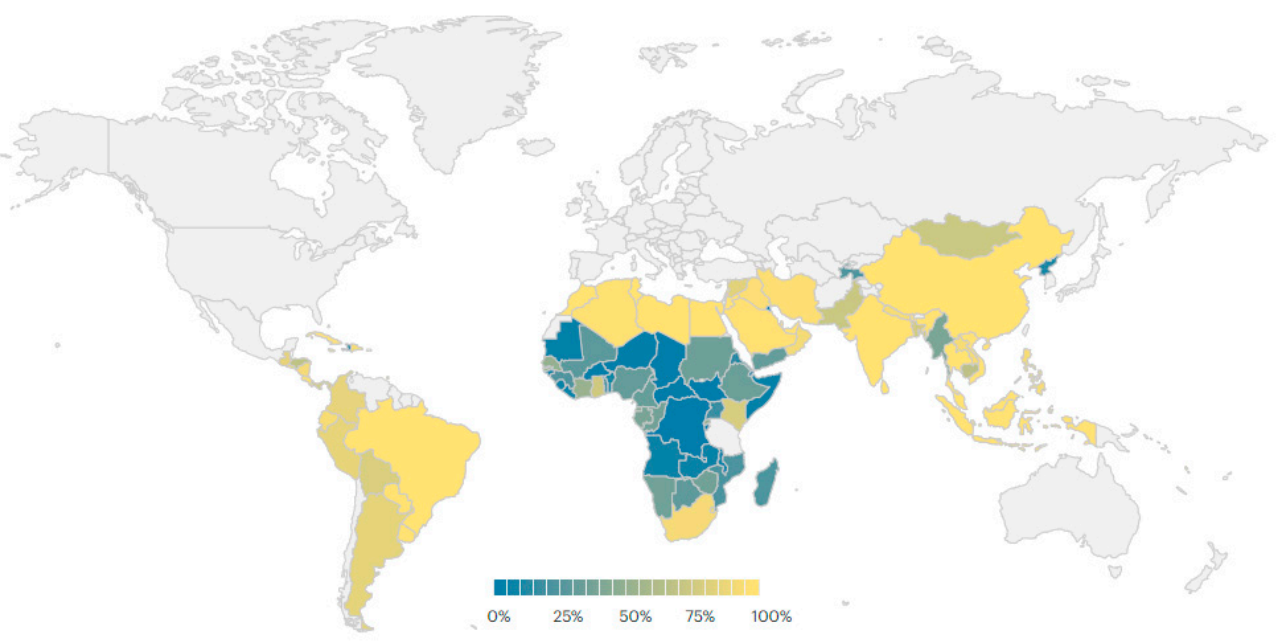

Figure 1. Rural population with access to electricity in 2019 [7].

However, it is now crucial to observe the effect of the COVID-19 pandemic that has significantly affected energy access, slowing down the efforts being made by directing resources primarily for health care [10]. In LAC, the pandemic forced them to take health protection measures that drastically reduced economic activity. The electricity demand fell between $6 \%$ and $32 \%$ in these countries [11], affecting the coverage expansion projects.

By 2019, except for Haiti (38.7\%) and Honduras (81.1\%), LAC countries have covered the population with electricity between $92.4 \%$ to $99.9 \%$ [7]. The coverage levels of electricity have been increasing in the LAC region, but the difficulty of achieving total coverage is also greater. For instance, in the Bolivian case, the electricity coverage increases very fast, and for 2019 reached $93.2 \%$ when the urban level was $99.3 \%$, and the rural was $79.3 \%$. Peru reported a total coverage of $97.0 \%$ and at the rural level, $86.3 \%$. Argentina, although it reports $98.8 \%$ total coverage and rural coverage of $84.9 \%$ [7], with a population of 44.56 million, in 2018, it reported that 120,000 rural families still did not have access to electricity $(0.8 \%$ of the population) [12]. For this region, Figure 2 shows the growth of electricity coverage between 1998 and 2018 and allows the appreciation that the electrification's annual rate decreases. Reaching the last mile of rural electrification is difficult and expensive [13,14].

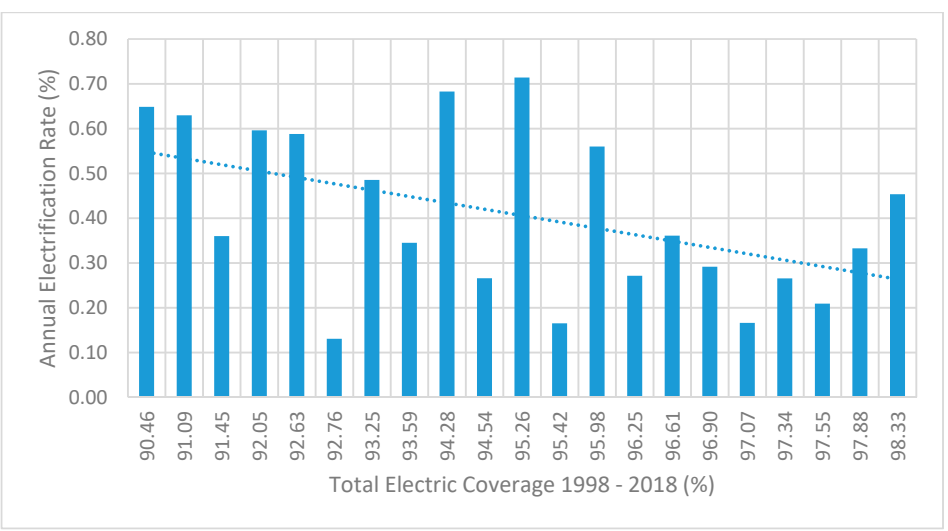

Figure 2. Annual electrification rate vs. total electric coverage in the Latin America and the Caribbean (LAC) region, 1998-2018. Based on data from the World Bank [15]. 
The high level of LAC coverage is the result of sustained actions in the energy sector by the countries, in correspondence with a global development agenda, which allows the active presence of multilateral funds and the active participation of civil society [16]. Likewise, the actors of the public and private electricity sector are regulated, and there is a context of economic growth and democracy [17].

A common aspect to all countries in LAC is that the people without access to electricity are mostly located in rural areas and have limitations to access to all services provided by a modern source of energy such as communication, information, and lighting [18,19]. Furthermore, the electric grid's extension reaches a cost-efficient limit, and the low density of households in rural areas without electricity makes it impossible to expand the grid. This situation is also aggravated by the high poverty level that reduces electricity access conditions, typical characteristics of isolated and dispersed rural populations in the LAC region [20]. In this context, decentralized solutions based on solar energy such as Solar Home Systems (SHSs) have been an extended option in many countries of the world since the beginning of the 1980s [21-23]. The Off-Grid Solar Market Trends Report 2020, for the period 2010-2019, estimated 84 million SHSs in the world at an operational level [24].

In different countries of LAC such as Brazil, Argentina, Peru, and Bolivia, etc., projects with Photovoltaic (PV) technology are implemented with different scales [17,25]. For instance:

- The "Light for All" program in Brazil, which began in 2003 until April 2018, has reached 16.2 million inhabitants of the rural area [26] through concessionaire electric companies directly. In the Amazon, due to the dispersed population, the most widespread solution was large SHSs [27].

- Argentina identified, in 2015, that there were still 145,000 isolated families without access to electricity [28], and this was the goal of PERMER II (Renewable Energy Project in Rural Markets), which launched an international tender in March 2018 to buy 120,000 SHSs to close the gap of existing electricity coverage.

- Peru, through a tariff scheme for isolated electric services, still executing its program of half-million SHSs, and in Bolivia is expected to reach 15,500 rural families with SHSs (and 14,500 families with grid extension) in the framework of the Infrastructure for Decentralized Rural Transformation-IDTR II project financed by the World Bank [29]. - Bolivia, in 2012 reported officially 31,544 families that have access to electricity through SHSs [30], as a result of different projects. For the period 2012-2015, different agencies reported new projects with more than 30,000 installations [31,32].

However, the SHS, while representing a widely accepted solution at a global level, was technically not always the same. Over time, the evolution of technology produced successive configurations in these systems and their components. The innovations, which have been carried out since the 1980s, have resulted in overcoming problems, difficulties, and generating impacts on rural families that use them. Therefore, the main contribution of this research is to help understand how the SHS configuration gradually changed due to technological advances and how these changes impacted the technical, economic, operational, and sustainability aspects of the SHS in rural areas. In this line, this article states the following research questions:

- What are the technological innovations in SHSs?

- Is it possible to identify these innovations in different periods and achieve a functional characterization?

- Will there be a new standard for photovoltaic electrification?

- What will be the implications for rural PV electrification actions?

This paper is organized as follows: Section 2 summarizes an initial discussion on rural electrification with SHSs; Section 3 describes the materials and methods used; Section 4 presents the evolution of SHSs technology; Section 5 presents the results obtained, and finally, Section 6 summarizes the main conclusions. 


\section{Rural Electrification with SHSs: Insights and Barriers}

The experiences, benefits, difficulties, and access models to electricity for the small and medium-size village, with a mini-grid based on decentralized technologies, have been studied by many authors. This solution involves planning, regulation, and specific policies for improving their impacts [33]. The mini-grids, additionally, need an optimal configuration to reach economic results and expand this option as a feasible solution $[34,35]$, with a technically correct field operation [36].

In the case of stand-alone systems for individual use such as SHSs, many researchers have reviewed their applications worldwide. The experiences of 20 World Bank's projects in different countries, such as Bangladesh, China, Vietnam, Sri Lanka, Argentina, Benin, Togo, Dominican Republic, and India, were evaluated, showing aspects such as business models, difficulties operating, and technical performance [37]. Nieuwenhout et al. (2001) carried out an extensive inventory of experiences of small PV systems projects, analyzing the cost, components quality, and access schemes for 104 projects from Africa, Asia, and LAC between 1992 to 2000 [22]. The main recommendation is the need of service infrastructure to make projects viable. Similarly, the field implementation, impacts, technical performance, and lessons learned from African SHSs projects were reported by Van Der Vleuten et al. (2007), showing that for a massive deployment of SHSs, among other aspects, active participation of public-private alliances is necessary and that rural entrepreneurs can be a key to sustainability [38]. On the other hand, several authors reported benefits and problems in the SHS use, as well as the management and financing models used in India [23], Bangladesh [39], and the evaluation of prices, financing structure, and the success in Bangladesh during the period 2002-2012 [40]. Focused on LAC, the rural electrification with decentralized applications of renewable energy and their impact was studied by different authors [21,41,42].

SHSs are undoubtedly an alternative to facilitate access to energy for rural populations without access to the electrical grid. However, its successful dissemination depends on a management system that integrally involves technical quality aspects, financing mechanisms appropriate for users' payment capacity, and clear roles of the actors involved.

Aligned to this, different technical analyses of SHSs components installed since 1990 to 2005 and focused on the quality of components [43,44] determine the need to apply quality programs to ensure technical sustainability and develop solar markets [45]. These reports also showed that the lead-acid batteries had been the weakest and the most expensive system component and are critical to achieving economic savings for end-user satisfaction [46]. A similar situation was already identified in 1999 in Kenya [47], in 2000 in India [48], in 2004 in Zambia [49], and for Bolivia, Brazil, Peru, and Argentina in 2006 [50]. For solar systems operators, the low reliability of lead-acid batteries has resulted in an expensive SHS operation and maintenance service [49]. In some cases, where governments regulate solar operators, these high costs may require high levels of subsidy. For instance, in Jujuy (Argentina), the end-user pays only 12.5\% of the full tariff (USD 26.59/month) and requires an operating subsidy of $87.5 \%$ [36]. For users, SHSs owners, these systems are inoperable after a few years, and solving small flaws or changing batteries is simply impossible [51]. Conversely, the PV module has proved to be the most reliable component technically with guarantees of at least 10 years and a lifetime of 20 years [47,48].

The most isolated families have no access to SHSs since the initial investment is too high for the target group: Rural low-income families with seasonal incomes and without access to financial services [52,53]. The need for periodic maintenance, which must be done by trained technicians, also implies an additional cost.

The technical configuration for SHSs used for rural electrification was similar in different countries of the world (Kenya, Philippines, China, Mexico, etc.), the components were a solar panel, a lead-acid battery, a regulator, loads, and accessories. The medium size of the SHS was $50 \mathrm{Wp}$ [54]. In LAC countries, the typical structure of SHSs in the mid-1990s was based on a photovoltaic module of around $50 \mathrm{Wp}$, an 8 Ampere (A) charge controller, a lead-acid battery of 100 Ampere hours (Ah), and three fluorescent lamps on 
average $18 \mathrm{~W}$ each, plus a DC (12 V) outlet for radio or TV [22,44]. However, during the last 20 years, significant technological innovations have been developed to introduce a new generation of photovoltaic systems. For instance, in the mid-2000 years, a series of technologies called pico PV broke out. With solar panels from 1 to $5 \mathrm{Wp}$ integrated as a format of solar lanterns and rechargeable batteries, these small photovoltaic systems grew rapidly $[55,56]$. As a consequence, field tests, market tests, etc. were carried out, studying the acceptance of these pico PV by certain strata of the population [57-60]. The Alliance for Rural Electrification [61] already incorporates the pico PV as a complementary option to SHSs, also, to calling for the use of more efficient equipment as a way to reduce the energy demand and size of photovoltaic systems [62,63].

In a fast process of evolution, the manufacturers of pico PV equipment incorporated in their designs new elements, such as Light-Emitting Diode (LED) lamps, microelectronics for control, rechargeable NiMh batteries, lithium-ion, lithium iron phosphate (coexisting with lead-acid batteries), showing a broad and diversified offer [64] and installation in rural areas of the world [65]. The International Finance Corporation (IFC) already shows a classification of three groups of equipment [66]: Rechargeable solar lanterns, solar kits, and the classic SHSs (see Figure 3).

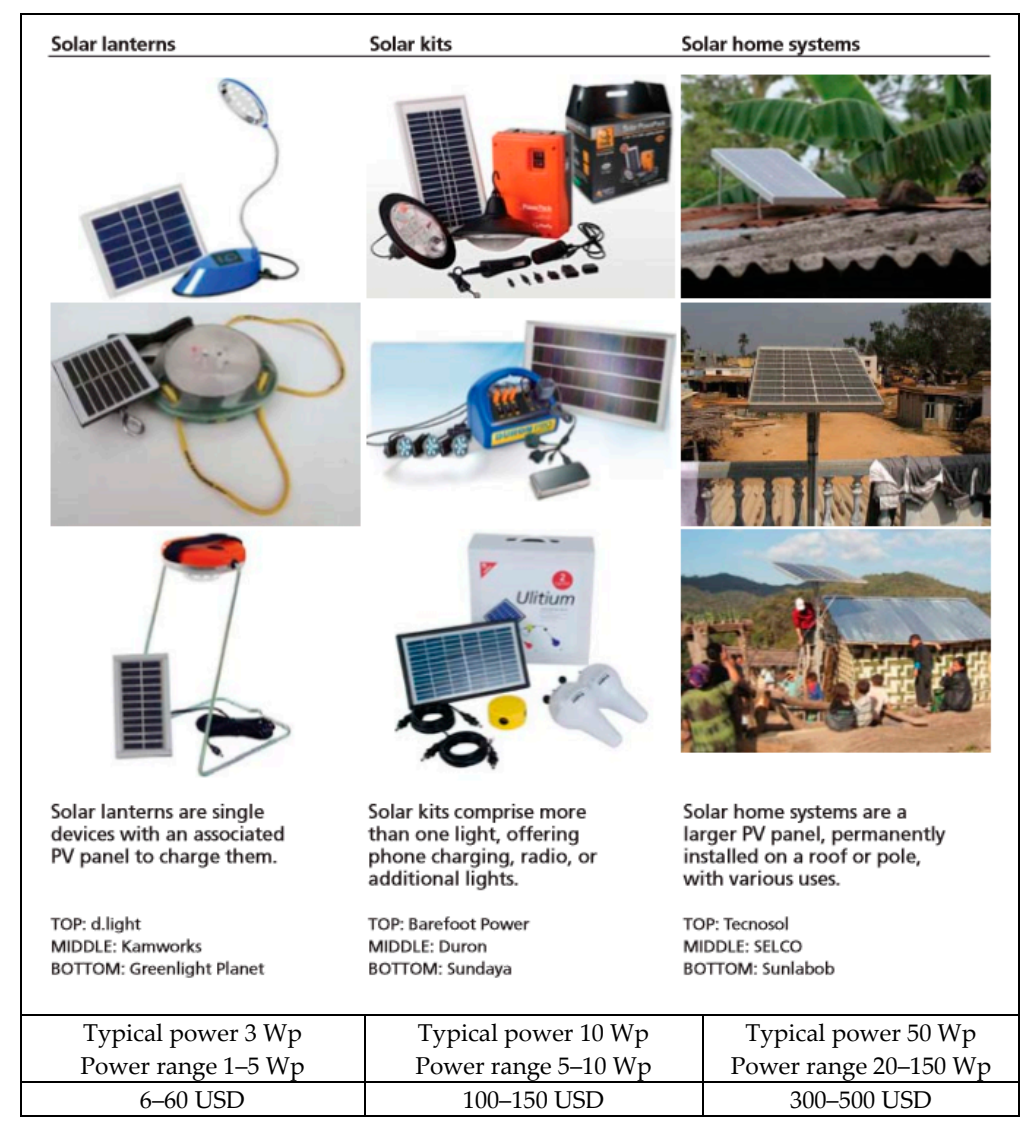

Figure 3. Solar rechargeable systems for lighting and electricity supply in homes [66].

In the market, the penetration of these new types of equipment was fast. At the end of 2017, it was estimated that 4.14 million solar lighting equipment or pico PV systems are providing services to rural families [67]. It is worth mentioning that the presence of this equipment produces tension for the project developers and, especially, for decision-makers. The wide and varied offer, few technical referents of performance, and absence of standards (compared to traditional SHSs) generate technical doubts about their quality. On the other hand, low costs, and the association with the idea of small systems that have less energy, reinforce a space of uncertainty that prevents them from seeing it as part of a valid option for providing the same services and from reducing the gap in universal access $[56,68]$. 


\section{Materials and Methods}

This article seeks to systematize the technological changes and innovations of SHSs over the last 30 years through a bibliographic review of experiences of PV electrification projects. Moreover, it identifies the main components and operational and functional aspects (PV generator, energy storage systems, charge control, and electrical connection of components). Projects of several world regions, technical reports, and articles available on online dating from the 1980s were reviewed, and documented references on the LAC region and specifically on Bolivia, Peru, and Argentina were searched and reviewed.

Since the 2000s, sources of information such as the International Renewable Energy Agency (IRENA), the Global Off-Grid Lighting Association (GOGLA), the Lighting for Africa, and the Lighting Global are institutions that are adding information and systematizing it, so their reports are considered in this study. Therefore, to have sufficient documentation on the countries under study, the information available on photovoltaic electrification programs implemented on a massive scale and the participation of governments and cooperation agencies has been considered. As a reference, in Argentina, the Project of Renewable Energies for Rural Markets (PERMER) works since 1999 and is executed by the government, reaching around 100,000 SHSs installations until 2018 [69]. With the project named Infrastructure for Decentralized Rural Transformation (IDTR), Bolivia supports the installation of 19,000 SHSs [31]. Finally, in Peru, different projects developed by the Ministry of Energy and Mines (MEM) through the General Directorate of Rural Electricity (DGER) reached near 20,000 SHSs installations in 2013 [70,71].

With the review of official information (reports, evaluations, terms of reference), technological and configuration changes in the SHSs are identified, selecting structurally important components (energy storage, load control, lighting, and electrical connections). The identified changes and the problems and challenges are analyzed and systematized, locating them in homogeneous periods to the reviewed projects.

Finally, to characterize the type of access to electricity that households have in different regions and social and economic realities, a technologically neutral and progressive multilevel standard comparison base called Access Tiers will be used [72]. Starting from a basic level, the ascent to the successive steps depends on the supply attributes that satisfy an increasing use of electrical equipment. We will use this internationally accepted base to compare the different SHSs access generations analyzed. Figure 4 shows the detail of each level.

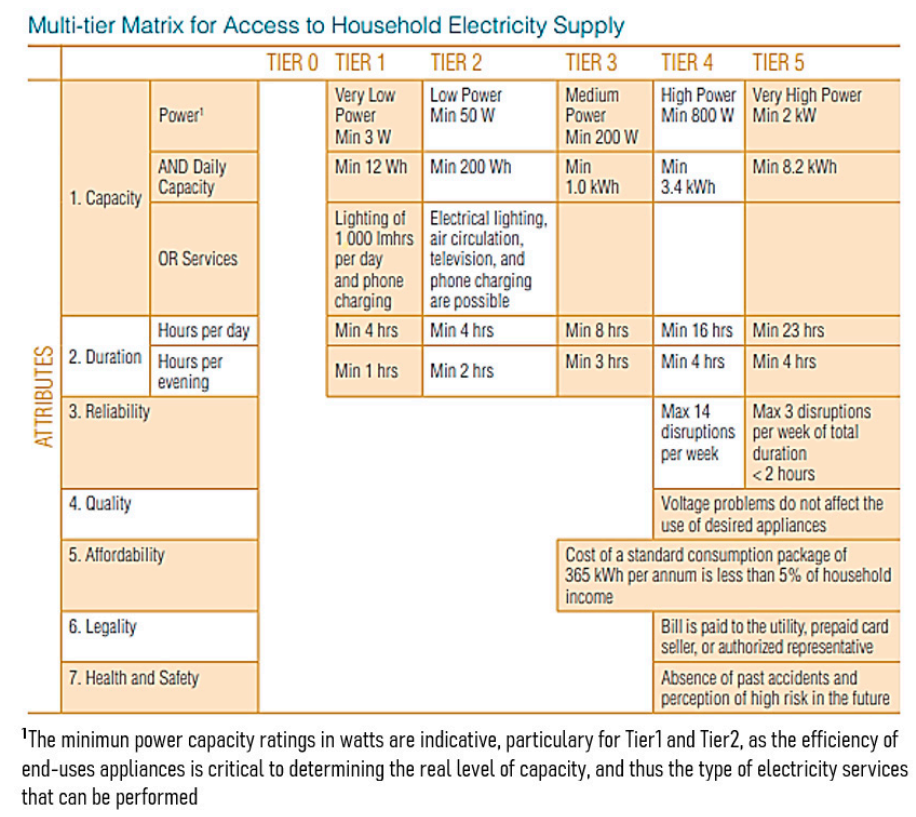

Figure 4. Access tiers. Matrix for measuring the access to household electricity [72]. 


\section{Technological Evolution of Solar Home Systems}

\subsection{SHSs in the Period 1980-1995}

SHSs used in isolated rural electrification made their appearance in the 1970s as demonstration projects. In 1978, PV systems for the rural application installed in the USA and other countries was reported, with a module cost of USD 14.7 to 18.3/Wp [73]. In the 1980s, the projects had a small-scale diffusion, and in the 1990s, large-scale dissemination [74].

In Latin America, the first photovoltaic electrification projects for families began in the 1980s. SHSs for rural electrification, with a commercial presence in the market since the 1980s, basically constituted a hybrid technology that used both the $12 \mathrm{~V}$ DC technology of cars and Alternating Current (AC) equipment adapted such as fluorescent lamps. These systems operate at $12 \mathrm{~V}$ DC. Problems with the fluorescent tubes were reported as a short lifetime (9 months), flickering and interference with radio were also identified [75]. A similar situation arose with the charge regulators that controlled the batteries, which in principle used the same concept of protection of automobiles, with electromechanical relays for the protection of the battery and fuses for automotive use. Finally, the batteries used to store energy were lead acid of automotive type [76]. Although these systems components were initially the product of local adaptations, gradually, with the expansion of the market, the production of components specifically for SHSs is standardized. Acceptance tests and technology on SHSs are reported since 1986 in Peru [21]. The first trials for what would later be the projects promoted by the German Cooperation in the region are given. In Bolivia, the Program for the Diffusion of Renewable Energies in Bolivia (PROPER), supported by the German Cooperation (GTZ), promote a technology transfer process for local production of ballasts for fluorescent lamps, electronic charge regulators, and the manufacture of solar batteries of lead acid [50] with the premise of ensuring quality. In this period, international products also began to position themselves in a global market, such as the Morning Star in the USA (a company founded in 1993, remains active) [77] or Steca in Germany (a company founded in 1976), a pioneer in supply charge regulators in the 1990s in LAC [78].

The mentioned characteristic for the SHSs installed in rural electrification projects between 1980 and 1995 had a typical configuration, named in this article the 1st Generation Solar Home Systems (1G-SHSs), a diagram of 1G-SHSs is shown in Figure 5.

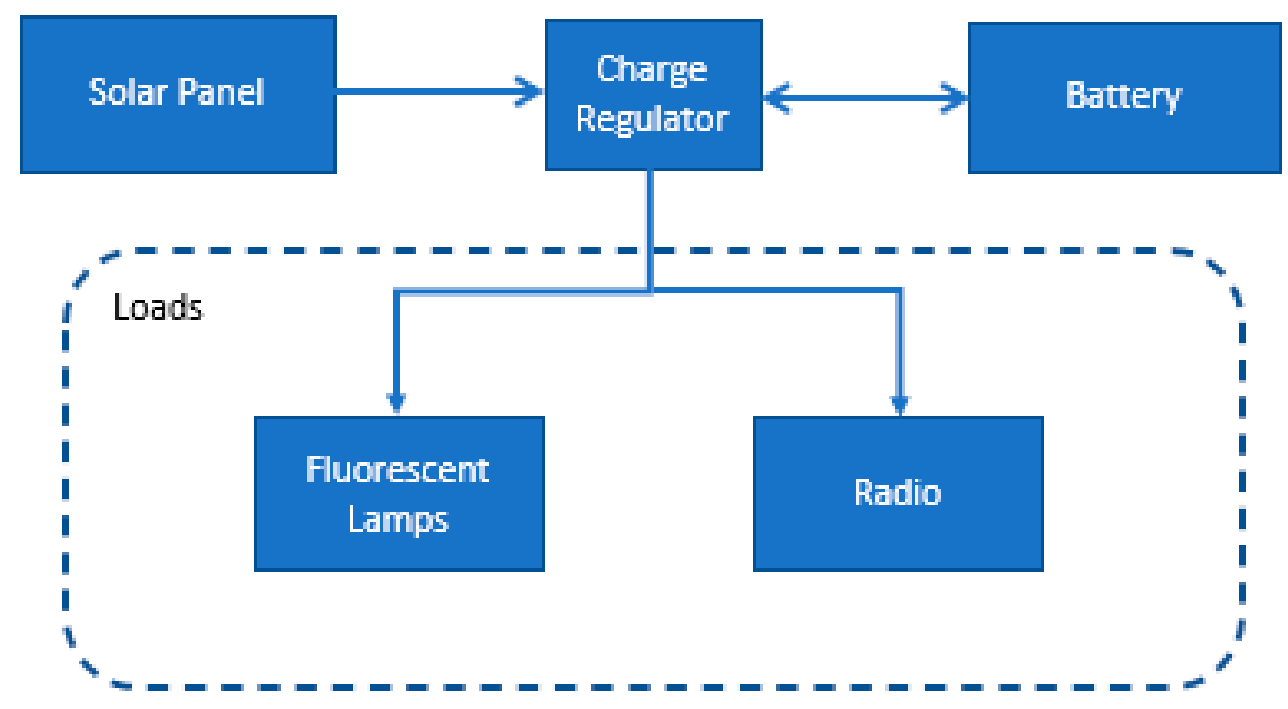

Figure 5. Scheme of the 1st generation solar home systems (1G-SHSs).

Despite the technical problems that the 1G-SHS had, its main achievement was to place a technology that came from space applications on the ground, to be used to electrify families in rural areas worldwide without access to conventional energy sources. 


\subsection{SHSs in the Period 1995-2010}

Between 1995 to 2000, an evolution process of PV technology produces a new generation of SHSs perceived. It is the use of equipment, components, and electronics specifically designed to use solar energy. Achieving an optimal use of the energy generated with photovoltaic panels defines this trend, and rural electrification projects incorporate SHSs as a formal alternative [40,79].

Concerns about the quality of components, their efficiency, and how to carry out the installations impulse the development and use of technical standards and protocols. In this context, the Universal Technical Standard for Photovoltaic Systems [80] was used regularly in LAC. In the Bolivian case, it served as a guide for the formulation of the Bolivian Standard NB 1056 that regulated the installation of SHSs up to $5000 \mathrm{Wp}$ [81]. In parallel, other initiatives such as the Global Approval Program for Photovoltaics (GAPPV) highlighted the need to ensure quality in photovoltaic systems [82].

The global acceptance of the technology as well as the most common technical problems are identified through technical field evaluations, intending to know the specific performance of the technology in different countries of the world such as Bangladesh [43,46] and Kenya [45]. The level of energy consumption of rural households that use SHSs is also analyzed [83]. Finally, the promotion of different PV applications [84] is part of the technology diffusion task during this period.

As a result of the technical recommendations, the solar industry gradually changed the SHSs components until reaching the following configuration: Photovoltaic panels of crystalline technology, solid-state electronic charge regulators (including automatic reset and electronic fuses), Compact Fluorescent Lamps (CFL) manufactured for $12 \mathrm{~V}$ DC, and lead-acid batteries adapted for specific use in solar systems (with terminals specially designed to prevent their automotive use). An integral part of the system was a DC-DC voltage adapter for radio (to allow radio connection of different voltages below $12 \mathrm{~V}$ (DC), and a socket for charge cellphones based on the car type (built around 2005, since the mobile phone grew in coverage). Finally, in areas with access to a television signal, the demand for this equipment also increased the offer of efficient Televisions (TVs) in $12 \mathrm{~V}$. These changes made a structure of 2nd Generation Solar Home Systems (2G-SHSs). A scheme of 2G-SHSs can be seen in Figure 6.

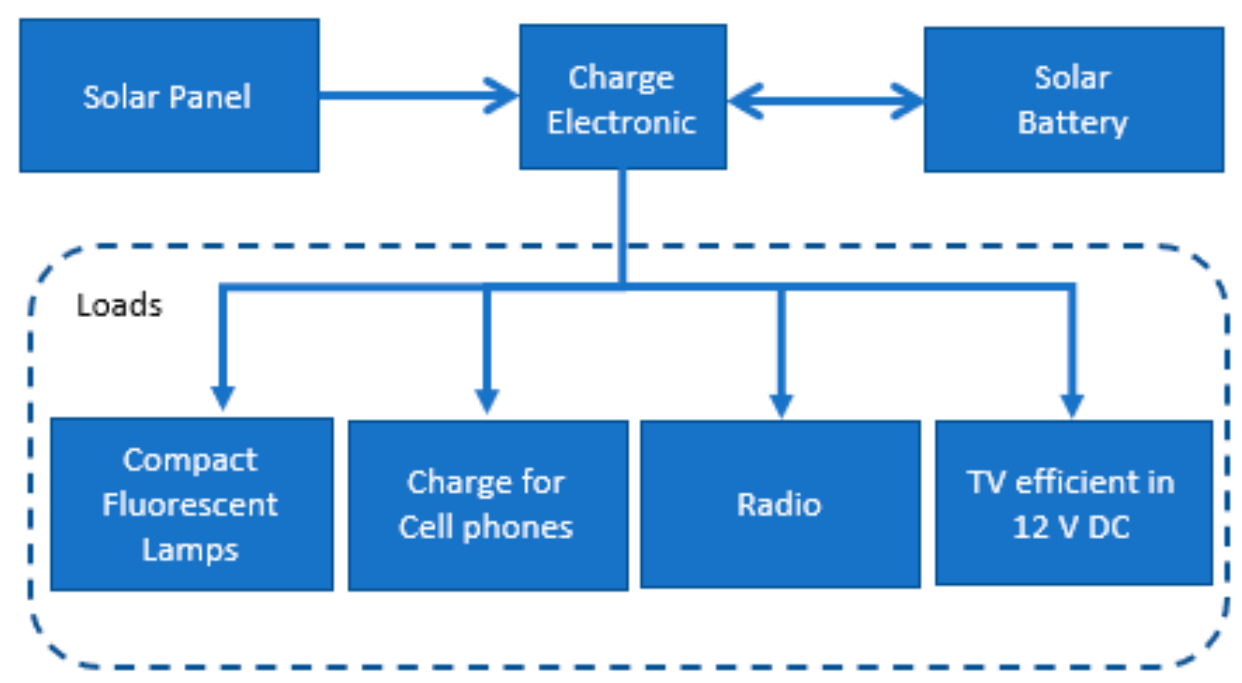

Figure 6. Scheme of 2nd generation solar home systems (2G-SHSs).

In Bolivia, the consolidation of scheme of 2G-SHSs becomes clear in 2004 with a tender to finance 15,000 SHSs for the World Bank [85] successfully implemented (a poster used to promote SHSs can be seen in Figure 7). Later in 2010, the Decentralized Electricity Project for Universal Access [31] launched a tender of 7067 SHSs. The technical specification of SHSs incorporates for the first time two LED lamps (over five lamps). It includes a 
solar lantern of 1600 pico PV with the condition that the equipment was on the Lighting Global product quality list. The Lighting Global support from the World Bank works with manufacturers, distributors, governments, and other development partners to build and grow a modern off-grid solar energy market with a widely applicable and rigorous Quality Assurance framework.

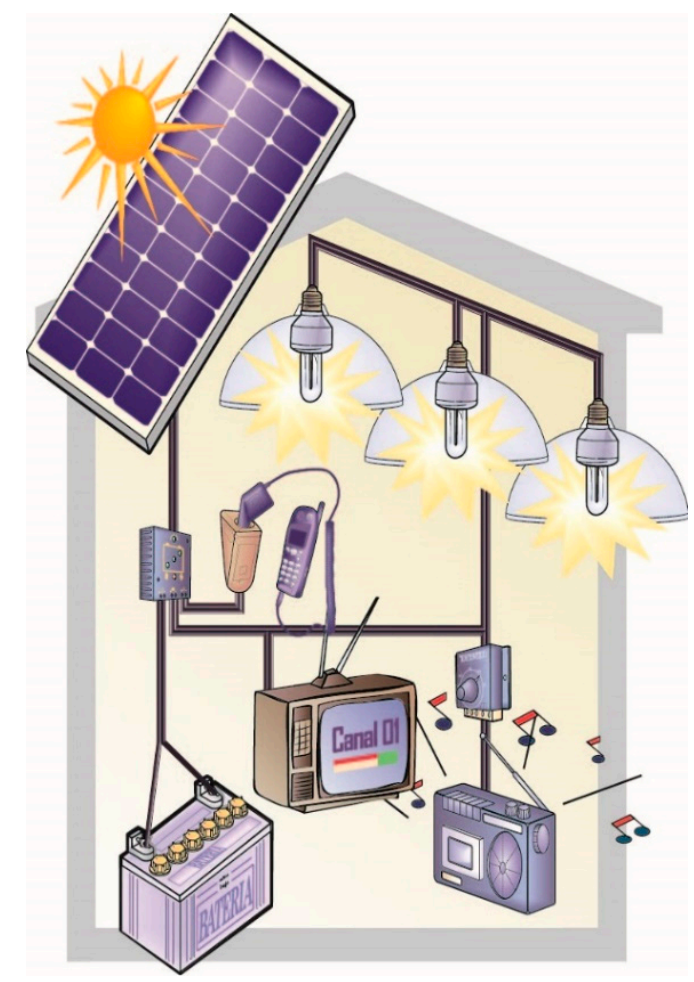

Figure 7. Poster of a 2G-SHSs used in Bolivian projects [86].

In 2013, in Peru, one of the largest LAC tenders was launched, which was intended to install 500,000 photovoltaic installations [71] and incorporate LED lamps [87]. Whereas, in Argentina, the PERMER project involved more than 100,000 SHSs installations [69,88], launched two tenders in 2016: One for 6500 SHSs (LPN no. 02/2016 in August) and another for 7500 SHSs (LPN no. 03/2016 in October). What is more, these 2G-SHSs have already started to incorporate LED lamps [12].

The 2G-SHS was the mature expression of the PV electrification technology for homes, with equipment specifically designed to optimize solar energy use, mobilizing the generation of internationally accepted norms and standards. Training materials for technicians and designers were also developed, as well as the standardization of bidding documents. All these elements made the 2G-SHS to be considered as a robust and accepted solution to supply electricity in rural areas.

\subsection{SHSs in the Period 2010-Until Now}

In the period 2005-2015, SHSs components had an accelerated change: On storage of energy (with the introduction of lithium batteries in replacement of lead-acid batteries) [64]; lighting (incorporation of LED lamps more efficient, more compact, and long life service); use of microelectronics in the control system (introducing small touch screen); and last by not least, the interconnection of the components had an upgrade with the introduction of plug and play connections [61]. The equipment named pico PV incorporates, in a progressive form, these innovations.

The pico PV offers a point of light and the capacity to charge a cell phone with solar panels below $10 \mathrm{Wp}$ [89]. However, a pico PV does not represent a substitution to the classic 2G-SHSs, which is considered the base configuration of PV electrification. Instead, a 
pico PV represents a step before the installation of an SHS due to the benefits it provides to the end-user, as identified by Feron (2016) and other authors [61,64,66,90,91]. However, without a doubt, getting households to have access to a pico PV that provides lighting and the capacity to charge mobile phones makes them enter Tier 1 on the scale of access to electricity [72] and marks the difference between not having access to electricity and starting the electrification process.

The load commonly covered by 2G-SHSs is associated with the electricity needs of a rural family: Three points of light for $3 \mathrm{~h}$ /day (with CFL from 7 to $11 \mathrm{~W}$ ), use of radio ( $8 \mathrm{~h}$ /day), TV and DVD player ( $27 \mathrm{~W}$ for $3 \mathrm{~h} /$ day), and charge at least one cell phone ( $6 \mathrm{~W}$ for $2 \mathrm{~h} /$ day). The total demand can reach $280 \mathrm{Wh} /$ day [92]. In this period (20052015), technological advances were migrating from pico PV to larger and more efficient applications, allowing a new type of SHSs to be configured. For instance, the introduction of LED lamps and the electricity demand reduction was analyzed for different countries in sub-Saharan Africa and South Asia, impacting the SHSs size and its cost reduction [93].

Once more efficient technologies were defined as a need, the same benefits of 2G-SHSs could be covered with $90 \mathrm{Wh}$ /day (using a $3 \mathrm{~W}$ LED lamp, $11 \mathrm{~W}$ flat-screen TV with a builtin DVD player, and 3 W USB cell phone charger). In 2015, a study by the Lawrence Berkeley National Laboratory showed that it was possible to cover the demand of a conventional SHS (600 lumens of illumination for $4 \mathrm{~h} /$ day, 19-inch TV $4 \mathrm{~h} /$ day, small radio $6 \mathrm{~h} /$ day, charge one cell phone per day) with a super-efficient SHS of only $25 \mathrm{Wp}$ [94], with the consequent reduction in costs, as shown in Figure 8.

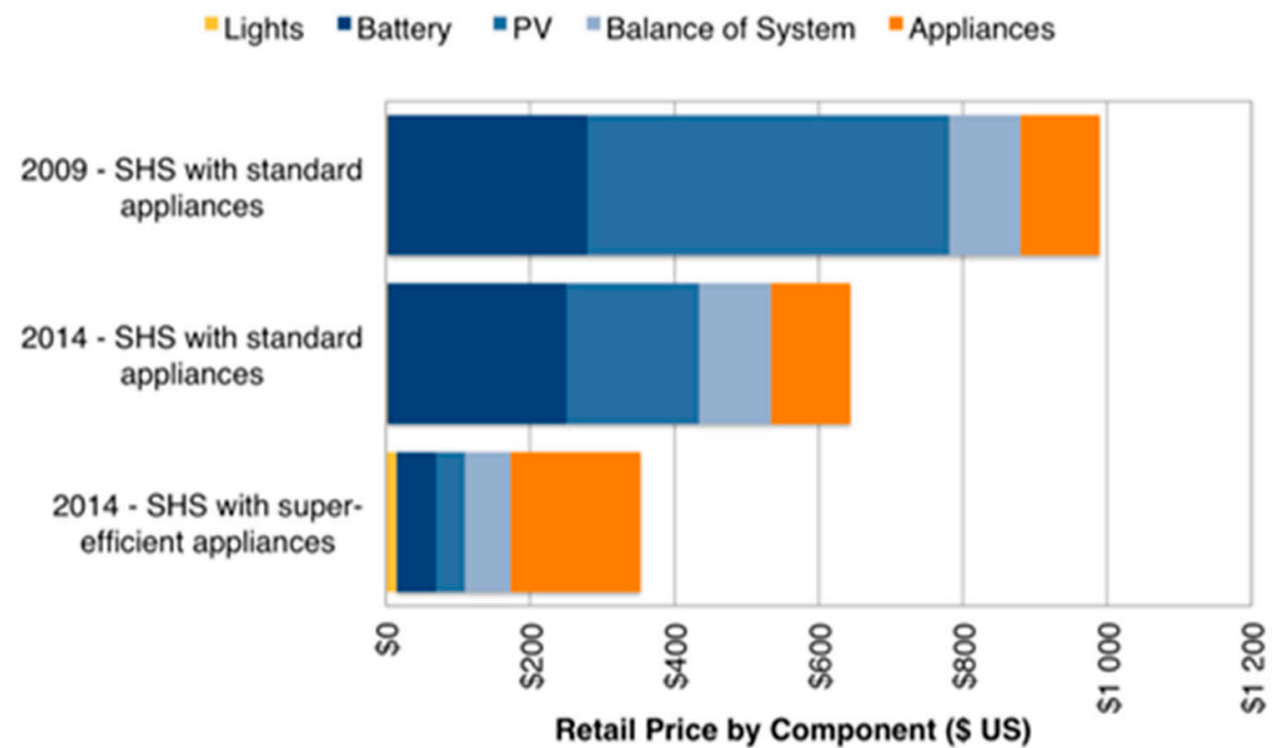

Figure 8. Retail prices for three types of solar house systems (SHSs) with identical benefits [94].

Due to the greater efficiency achieved in lighting with LED technology [63], LCD TVs, radios of lower consumption, and more efficient cell phones, a significant reduction of the need for electricity in new SHSs was achieved, which avoids unnecessary oversizing of SHSs and reduces the investment cost. On the other hand, in recent years, the increase in appliances' efficiency has been impressive $[95,96]$. Increased efficiencies in televisions, fans, and refrigerators will allow future growth in off-grid households' energy services, allowing more services with smaller SHSs, and rethinking the Access Tiers' reference power ranges.

The use of high-efficient applications, the incorporation of lithium batteries, and the innovations detected allows a new configuration for SHSs with significant differences in respect to 2G-SHSs. These new SHSs are named 3rd Generation Solar Home Systems (3G-SHSs), as shown in Figure 9. 


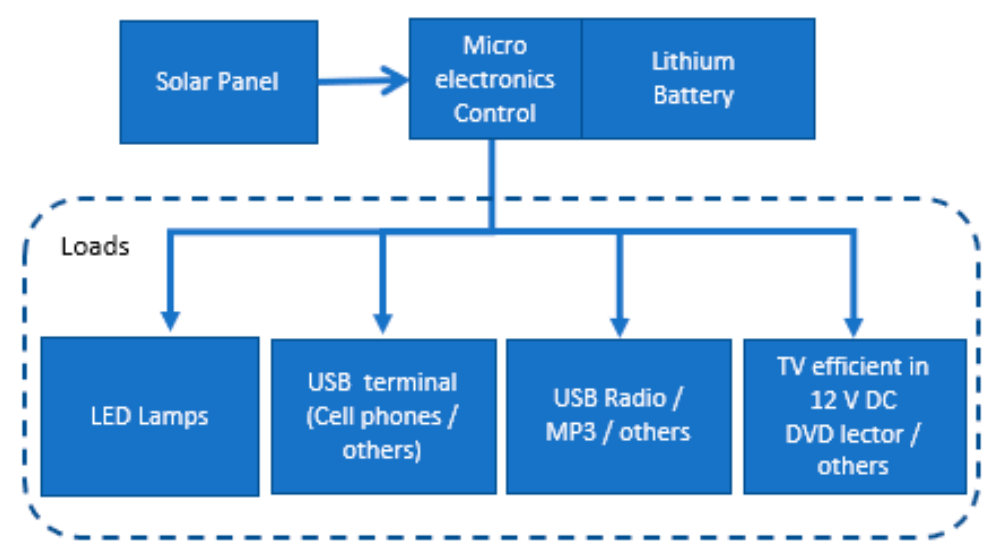

Figure 9. Scheme of 3rd generation solar home systems (3G-SHSs).

In this context, a 3G-SHS incorporates technological innovations in a comprehensive, efficient, and compact design, as detailed below:

- Use of rechargeable batteries of high density and small size, essentially lithium iron phosphate, replacing lead-acid batteries.

- Microelectronics control is incorporated in the same battery. The system does not require an electronic charge controller as a separate equipment and has additional capabilities associated with a microprocessor (communication, data storage, and display).

- Use of LED lamps as an integral part of the equipment to make efficient use of energy in lighting, and availability of outputs for powering equipment with the standard USB port.

- A compact integrated design, lighting, easy to install, and no need to make electrical connections (plug and play logic).

As an example, the configuration of 3G-SHSs used in Bolivia is shown in Figure 10.

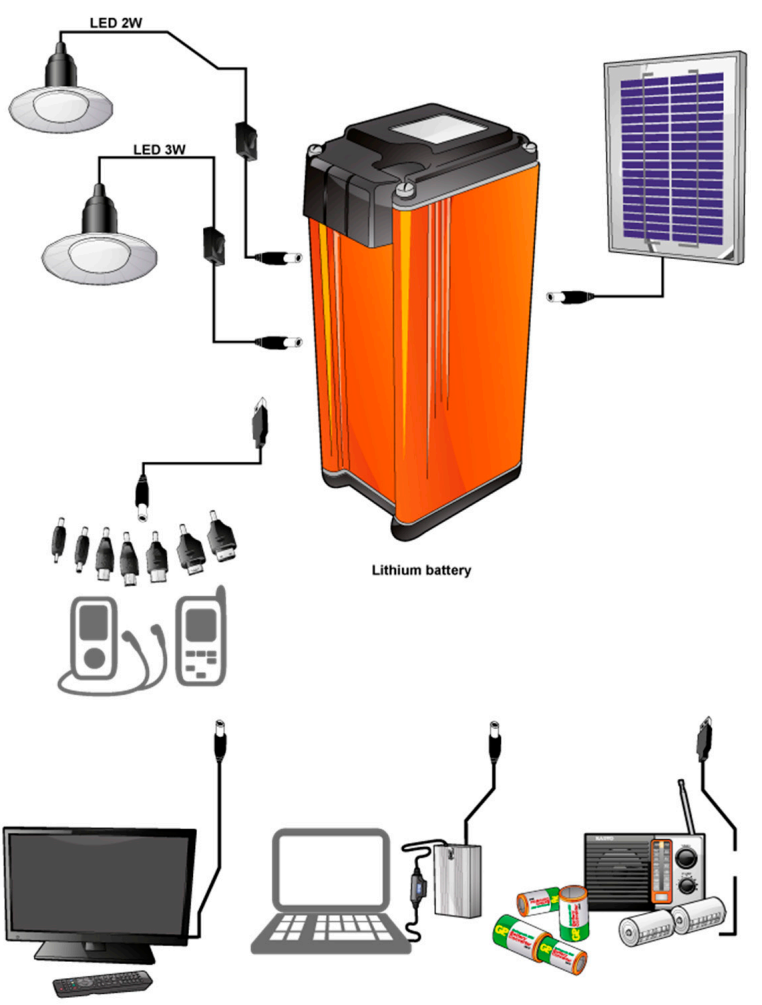

Figure 10. Poster of 3G-SHSs used in Bolivian projects [97]. 
The use of 3G-SHSs was reported almost 10 years ago, and with clear advantages over 2G-SHSs in economic, technical, and logistical aspects. Eras-Almeida et al. reported experiences in Mexico, Peru, and Bolivia in 2019 [98], where additionally business models to facilitate the implementation of 3G-SHSs are tackled. The authors concluded that 3G-SHSs are the most suitable solution in terms of economic, social, and environmental efficiency.

Undoubtedly, the 3G-SHSs have a singular configuration: Compact dimensions, highefficient components, and capacity for interaction through microelectronics that gives multiple possibilities of operability to provide access to electricity in the most remote locations in LAC.

\section{Results and Discussion}

\subsection{Time Sequence of SHSs Components Innovation}

Over the last 30 years, there have been different technological innovations in SHSs. An analysis of these changes, disaggregated by SHS components, allows structural modifications to be identified in four components: (a) The energy storage, (b) lighting technology and new energy demands, (c) the electronic control system, and (d) the connections and installation form of the systems. All these identified modifications are described below.

\subsubsection{Energy Storage}

The 1G-SHSs used automotive car batteries due to the lack of technology of energy storage for solar systems. While 2G-SHSs use lead-acid batteries specially adapted for solar use (open or sealed) with modifications in terms of dimensions (due mainly to the increase in the plates' thickness). The change of terminals prevents automotive use. In addition, 3G-SHSs use lithium rechargeable batteries of different configurations with big advantages in lifespan, lower weight, minimum maintenance, and lower costs [99]. In this sense, it is possible to leap the classic lead-acid accumulator to use portable rechargeable lithium batteries [100]. Figure 11 shows the changes in energy storage for SHSs.

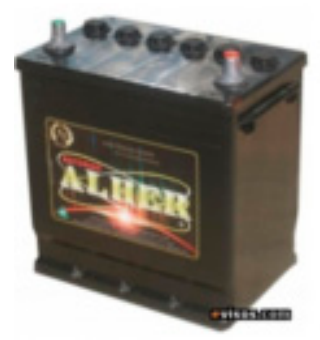

(a)

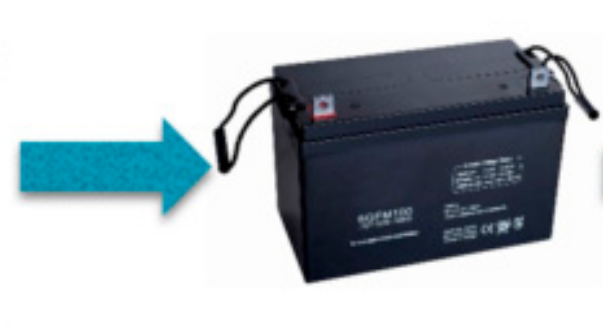

(b)

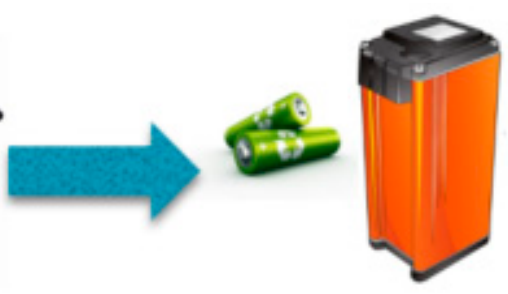

(c)

Figure 11. Changes in batteries for energy storage in SHSs [100]. (a) 1G-SHSs: Lead-acid automotive battery, (b) 2G-SHSs: Lead-acid solar battery, (c) 3G-SHSs: Lithium battery (Phocos, Germany).

\subsubsection{Lighting and New Charges}

The first installations of 1G-SHSs used fluorescent tubes of $18 \mathrm{~W}$ which was a standard for photovoltaic electrification. These fluorescent lamps manufactured to work with reactors in $220 \mathrm{~V}$ AC were used to work with electronic ballasts that made its use possible at $12 \mathrm{~V}$ DC. Whereas, 2G-SHSs used Compact Fluorescent Lamps (CFL) designed for $12 \mathrm{~V}$ DC with specific characteristics to extend their useful life (preheating and temperature control), the high efficiency, and the use of the E47 thread as a universal connection format, quickly displaced the use of fluorescent tubes. However, the new technological leap uses LED, given the high efficiency and low energy consumption, its long life, and downward costs [101], making their use mandatory in 3G-SHSs. Figure 12 shows the evolution of lighting technologies graphically for SHSs. 


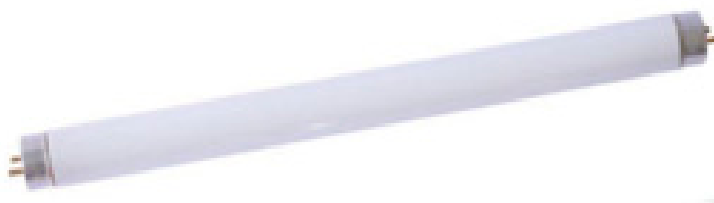

(a)

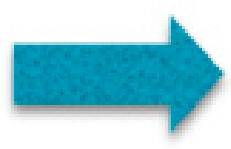

(b)
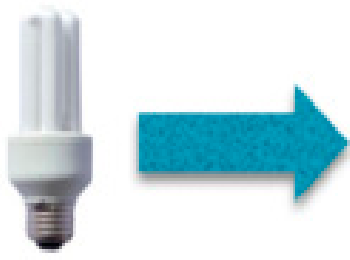

(c)

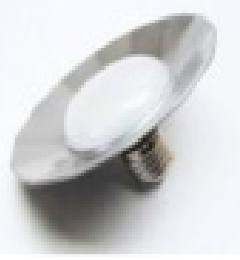

Figure 12. Changes in lighting technologies used in SHS [100]. (a) 1G-SHSs: Fluorescent tubes of 18 W; (b) 2G-SHSs: CFL lamps (8 to $15 \mathrm{~W}$ ); (c) 3G-SHSs: Light-emitting diode (LED) lamps (3 to $5 \mathrm{~W}$ ).

Other types of equipment such as cell phones, DVD players, or flat-screen TVs have also improved their efficiency, and many require USB connections.

\subsubsection{Control System}

The 1G-SHSs used load controllers based on electromechanical components, such as relays, automotive fuses that were the most widespread security element, cylindrical type initially and then of bayonet type. 2G-SHSs use the electronic solid-state regulators and have LED lights indicators, clearly differentiated connection ports, and electronic self-reset fuses. The next change (3G-SHSs) has incorporated microelectronics in control, small circuits with high control capabilities, aimed at controlling lithium batteries, which require more specific cell control than the case of lead-acid batteries. Regulators are currently integrated into the lithium batteries and incorporate a small high-definition screen with user-friendly iconography that shows information about the state of charge, connections, and remaining hours of autonomy, recalculated automatically. These regulators are an important component of 3G-SHSs. Figure 13 shows the identified changes in regulators.

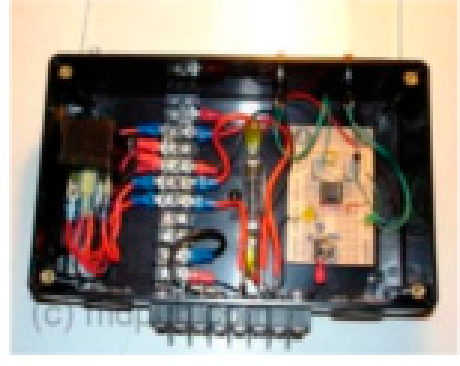

(a)

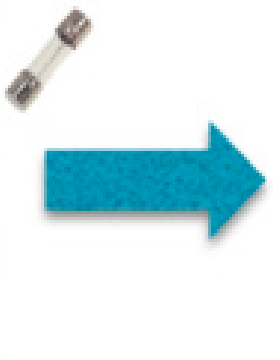

(b)

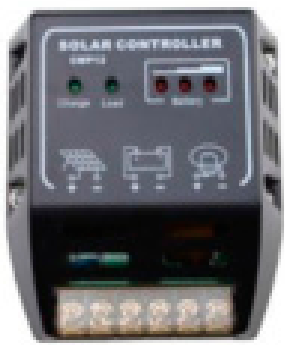

b)

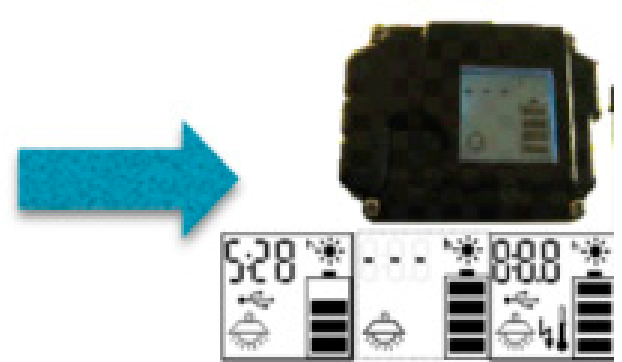

(c)

Figure 13. Change in SHS load regulators [100]. (a) 1G-SHSs: Electromechanical load regulator; (b) 2G-SHSs: Electronic solid-state regulator; (c) 3G-SHSs: Microelectronic regulator.

\subsubsection{Connections and Installation}

The evolution of electric connections is possible to see in Figure 14. The electrical connections of 1G-SHSs were normally made through splices in the conductors that had to be isolated later (the Bolivian standard NB1056 included an annex on the best way to make splices). For 2G-SHSs, generic connectors are incorporated as a standard of installations, eliminating splices and insulating tape, thus reducing the points of failure. On the contrary, 3G-SHSs use connectors specifically designed under a plug and play logic. Thus, it is easy to interconnect modules, loads, batteries, using universal ports. This makes 3G-SHSs installations much faster and extremely safe, avoiding errors, and making self-installation possible without a specialized technician. 


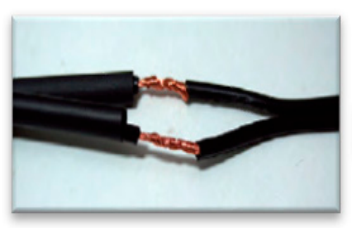

(a)

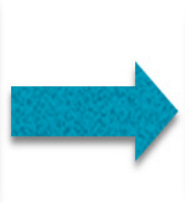

$(\mathbf{b})$

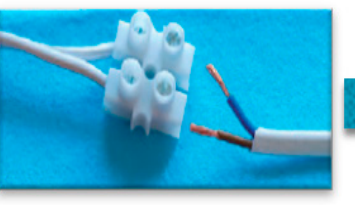

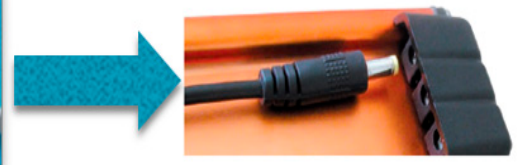

(c)

Figure 14. Changes in the way electrical connections are made in SHS [100]. (a) 1G-SHSs: Splices in electrical wires; (b) 2G-SHSs: Connectors for electrical use; (c) 3G-SHSs: Plug and play connectors.

Under these four aspects, it is possible to appreciate the technological changes, which occur progressively and coincidentally in certain periods, allowing SHSs to be classified into three generations of SHSs. From which, the most efficient configuration, 3G-SHSs, has resulted in a fast deployment of installations to supply electricity demand in the hardest-to-reach rural areas, as a consequence of shorter installation times, the possibility of installation by non-specialized personnel, the simplicity of operation, and, above all, the absence of the need for periodic maintenance. Moreover, the battery's microcontroller opens possibilities for regulation, control, data collection, and an online connection to add a mobile payment system. The combination of all these technological innovations and their consequent changes in economic aspects, useful life, operation, and maintenance, opens the possibilities of developing new business models oriented to the population without access to energy at the base of the pyramid.

\subsection{Technical Characterization of 3G-SHSs and Differences}

A systematization of the technical characteristics of the three generations of SHSs is carried out, considering the following technological variables: Power generation, lighting, energy storage, regulation, wiring and connections, installation, operation and maintenance. In each item, a detail of specific topics exists with values or short descriptions, which allows us to appreciate the changes incorporated in each generation of SHSs. A synthesis of detected changes in the different generations of SHSs is shown in Table 1.

Table 1. Synthesis matrix of detected changes.

\begin{tabular}{|c|c|c|c|c|}
\hline Component & Variable & $\begin{array}{c}\text { First Generation } \\
\text { 1980-1995 }\end{array}$ & $\begin{array}{c}\text { Second Generation } \\
\text { 1995-2010 }\end{array}$ & $\begin{array}{c}\text { Third Generation } \\
\text { 2010- }\end{array}$ \\
\hline \multirow[t]{2}{*}{ Generation } & Technology & $\begin{array}{l}\text { Mono or Poly Crystalline } \\
\text { Photovoltaic Panels }\end{array}$ & $\begin{array}{l}\text { Mono or Poly Crystalline } \\
\text { Photovoltaic Panels }\end{array}$ & $\begin{array}{l}\text { Mono or Poly Crystalline } \\
\text { Photovoltaic Panels }\end{array}$ \\
\hline & Capacity & $50 \mathrm{Wp}$ & 50-80 Wp & $20-50 \mathrm{Wp}$ \\
\hline \multirow{5}{*}{ Lightning } & Type & Fluorescent (TL) & $\begin{array}{l}\text { Compact Fluorescent } \\
\text { (CFL) }\end{array}$ & LED \\
\hline & Required power & $18 \mathrm{~W}$ & $7-11 \mathrm{~W}$ & $3 \mathrm{~W}$ \\
\hline & Life Spam & 5000 to $8000 \mathrm{~h}$ & 8000 to $10,000 \mathrm{~h}$ & $50,000 \mathrm{~h}$ \\
\hline & Efficiency & $4 \mathrm{~lm} / \mathrm{W}$ & $60 \mathrm{~lm} / \mathrm{W}$ & $100 \mathrm{~lm} / \mathrm{W}$ \\
\hline & Electronic & Tubes with electronic ballast & $\begin{array}{l}\text { Lamp with E47 thread (for } \\
\text { a conventional socket) and } \\
\text { electronic incorporated }\end{array}$ & $\begin{array}{l}\text { Lamp with E47 thread (for } \\
\text { a conventional socket) and } \\
\text { electronic incorporated }\end{array}$ \\
\hline \multirow{5}{*}{ Storage } & Type & Lead Acid-Automotive & Lead Acid-Solar & $\begin{array}{l}\text { Lithium-Ion and Lithium } \\
\text { Iron Phosphate-Solar }\end{array}$ \\
\hline & Life cycles & 1000 & 1500 & $2500-3000$ \\
\hline & Discharge depth & $30 \%$ normal, $50 \%$ maximum & $\begin{array}{l}30 \% \text { normal, } 50 \% \\
\text { maximum }\end{array}$ & $100 \%$ (nominal) \\
\hline & Typical capacity & 100-120 Ah & 100-120 Ah & 6-10 Ah \\
\hline & Energy density & 30-35 Wh/kg & $35-40 \mathrm{Wh} / \mathrm{kg}$ & 90-125 Wh/kg \\
\hline
\end{tabular}


Table 1. Cont.

\begin{tabular}{|c|c|c|c|c|}
\hline Component & Variable & $\begin{array}{l}\text { First Generation } \\
\quad 1980-1995\end{array}$ & $\begin{array}{c}\text { Second Generation } \\
1995-2010 \\
\end{array}$ & $\begin{array}{l}\text { Third Generation } \\
\text { 2010- }\end{array}$ \\
\hline \multirow{3}{*}{ Regulator } & Type & Electromechanics & Solid-state electronics & Microelectronics \\
\hline & User interface & $\begin{array}{l}\text { Fault relays open the circuit. } \\
\text { Restitution by the user }\end{array}$ & $\begin{array}{l}\text { Information by LEDs of } \\
\text { different states of charge } \\
\text { and troubles }\end{array}$ & $\begin{array}{l}\text { Icons, with clear } \\
\text { information to the user }\end{array}$ \\
\hline & Protections & Automotive fuses & $\begin{array}{l}\text { Electronic fuses for } \\
\text { automatic restitution }\end{array}$ & $\begin{array}{l}\text { Fully integrated internal } \\
\text { protection }\end{array}$ \\
\hline \multirow{4}{*}{$\begin{array}{l}\text { Cabling and } \\
\text { connectors }\end{array}$} & Type & Bicolor & Bicolor & Armored \\
\hline & Cabling design & $\begin{array}{l}\text { Follow technical rules for } \\
\text { installations }\end{array}$ & $\begin{array}{l}\text { Follow technical rules for } \\
\text { installations }\end{array}$ & $\begin{array}{l}\text { Pre-set lengths, with a } \\
\text { switch already connected }\end{array}$ \\
\hline & Connection methods & $\begin{array}{l}\text { Splices and twisted leads, } \\
\text { insulation with electric tapes }\end{array}$ & $\begin{array}{l}\text { Connectors are used } \\
\text { instead of splices }\end{array}$ & $\begin{array}{l}\text { Direct connection with } \\
\text { specific terminals (plug } \\
\text { and play) }\end{array}$ \\
\hline & Polarity & $\begin{array}{l}\text { Observe polarity, problems in } \\
\text { short-term splices }\end{array}$ & Observe polarity & $\begin{array}{l}\text { Each terminal is specific } \\
\text { for its use }\end{array}$ \\
\hline \multirow{3}{*}{ Installation } & Equipment weight & $50 \mathrm{~kg}$ & $50 \mathrm{~kg}$ & $6 \mathrm{~kg}$ \\
\hline & Complexity & Need specialized technician & $\begin{array}{l}\text { Need specialized } \\
\text { technician }\end{array}$ & Minimum \\
\hline & Human resource & Specialized & Specialized & End-user \\
\hline \multirow{5}{*}{ Operation } & Training & $\begin{array}{l}\text { Manuals and explanation to } \\
\text { the user }\end{array}$ & $\begin{array}{l}\text { Manuals and explanation } \\
\text { to the user }\end{array}$ & $\begin{array}{l}\text { Posters, manuals, detailed } \\
\text { explanation to the user }\end{array}$ \\
\hline & SHS operation & End-user & End-user & End-user \\
\hline & Connections & $\begin{array}{c}\text { Connection made only by } \\
\text { technicians }\end{array}$ & $\begin{array}{l}\text { Connection made only by } \\
\text { technicians }\end{array}$ & $\begin{array}{c}\text { Connect/disconnect by } \\
\text { end-user }\end{array}$ \\
\hline & Adapters & & $\begin{array}{l}\text { Use of adjustable DC-DC } \\
\text { adapters depending on } \\
\text { the load }\end{array}$ & $\begin{array}{l}\text { Fixed outputs in } 12 \text { and } \\
5 \mathrm{~V} \text { (USB) }\end{array}$ \\
\hline & Risk & $\begin{array}{l}\text { Short circuit hazards on } \\
\text { battery terminals. Polarity }\end{array}$ & $\begin{array}{l}\text { Short circuit hazards on } \\
\text { battery terminals. Polarity }\end{array}$ & No particular danger \\
\hline \multirow{7}{*}{ Maintenance } & Training & Training a technician & Training a technician & $\begin{array}{l}\text { Training the user to take } \\
\text { the component that fails } \\
\text { and carry it to the } \\
\text { technical center }\end{array}$ \\
\hline & Module & Cleaning & Cleaning & Cleaning \\
\hline & Regulator & Cleaning and adjustments & Cleaning and adjustments & \\
\hline & Battery & Cleaning added distilled water & $\begin{array}{l}\text { Cleaning added } \\
\text { distilled water }\end{array}$ & Cleaning \\
\hline & Charges & Cleaning and adjustments & Cleaning and adjustments & Cleaning \\
\hline & Adapters & & Cleaning and adjustments & \\
\hline & Consideration & $\begin{array}{l}\text { In case of failure, call the } \\
\text { technician }\end{array}$ & $\begin{array}{l}\text { In case of failure, call the } \\
\text { technician }\end{array}$ & $\begin{array}{l}\text { In case of failure, bring the } \\
\text { component to the } \\
\text { technician }\end{array}$ \\
\hline \multirow{3}{*}{$\begin{array}{c}\text { Energy Services } \\
\text { Offered in Bolivian } \\
\text { projects }[31,32,86]\end{array}$} & Energy Services & $\begin{array}{c}3 \text { point of light }(\mathrm{TL} 18 \mathrm{~W} \\
9 \mathrm{~h} / \mathrm{d} \text { total }) \\
1 \text { radio }(12 \mathrm{~W}, 6 \mathrm{~h} / \mathrm{d}) \\
1 \text { TV DC Black and White } \\
12 \text { inch }(20 \mathrm{~W}, 2 \mathrm{~h} / \mathrm{d})\end{array}$ & $\begin{array}{c}3 \text { point of light }(\mathrm{CFL} 7 \mathrm{~W}, \\
9 \mathrm{~h} / \mathrm{d} \text { total }) \\
1 \text { radio }(10 \mathrm{~W}, 6 \mathrm{~h} / \mathrm{d}) \\
1 \mathrm{TV} \text { flat } \mathrm{DC}-\text { Color } \\
14 \text { inch }(14 \mathrm{~W}, 3 \mathrm{~h} / \mathrm{d}) \\
\text { Charge Cell Phone }\end{array}$ & $\begin{array}{c}3 \text { point of light }(\text { LED } 3 \mathrm{~W} \text {, } \\
9 \mathrm{~h} / \mathrm{d} \text { total }) \\
1 \text { radio }(4 \mathrm{~W}, 6 \mathrm{~h} / \mathrm{d}) \\
1 \text { TV flat } \mathrm{DC}-\text { Color } \\
15.6 \text { inch }(10 \mathrm{~W}, 3 \mathrm{~h} / \mathrm{d}) \\
\text { Charge Cell Phone }\end{array}$ \\
\hline & Wh/day & 274 & 183 & 96 \\
\hline & $\begin{array}{l}\text { Access } \\
\text { Tiers }\end{array}$ & Tier 2 & Tier 2 & Tier 2 \\
\hline
\end{tabular}


It can see that the three generations of SHSs offer the same energy services corresponding to Tier 2. Likewise, the increase in efficiency is observed, which for the same services goes from $274 \mathrm{Wh}$ /day with the 1G-SHS to $183 \mathrm{Wh}$ /day with 2G-SHS and finally at $96 \mathrm{Wh} /$ day with 3G-SHSs. By the way, the component costs for the three generations of SHS have been compiled from projects carried out in Bolivia $[31,32,86]$. Following the line of analysis of Phadke [94], Figure 15 shows the results obtained that validate the cost reduction attributed to the $3 \mathrm{G}-\mathrm{SHS}$.

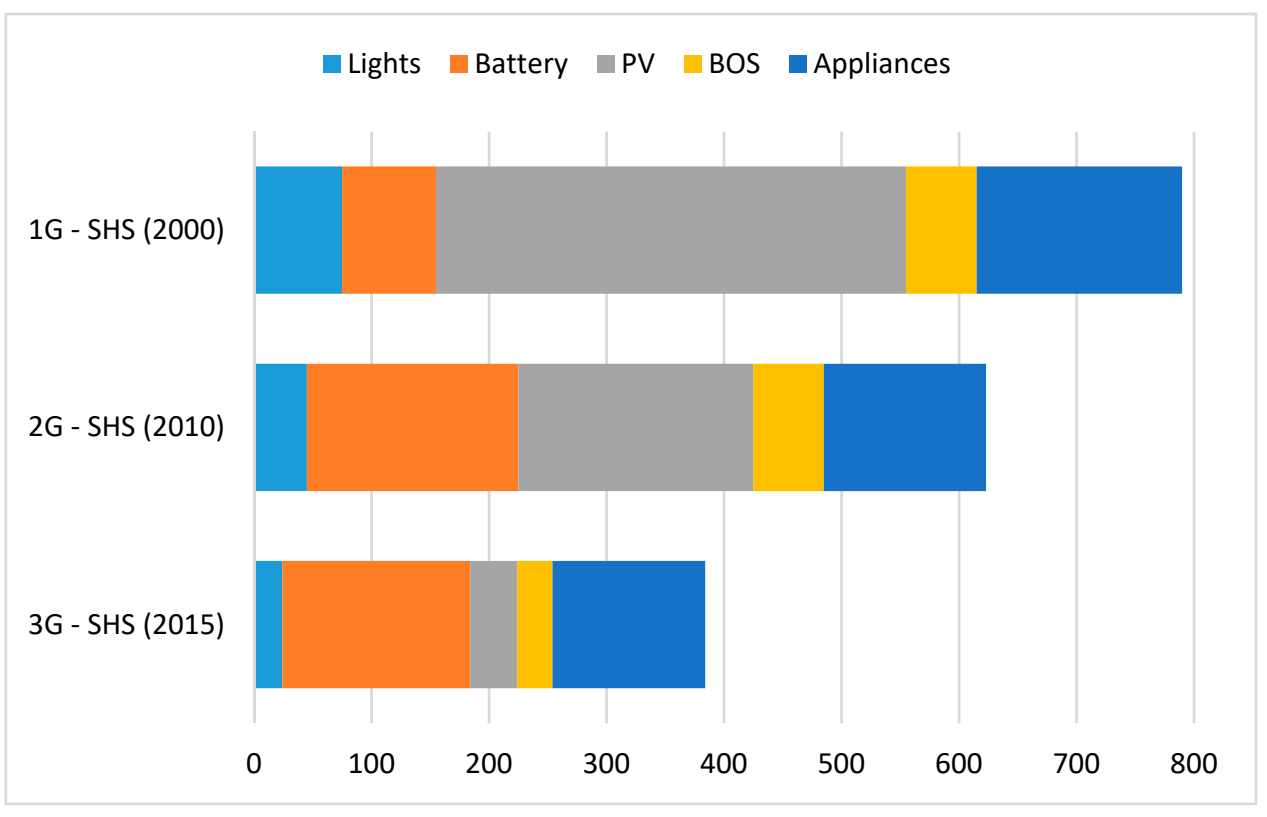

Figure 15. Cost of components for three generations of SHSs in Bolivia to satisfy demands of Tier 2, with data of [31,32,86].

Reviewing the technical characteristics of 3G-SHSs concerning their previous versions, the positive differences and advantages lead us to think that the photovoltaic electrification for rural households must necessarily turn towards a wide use of 3G-SHSs (with quality certification), becoming a new standard for this application. It is important to emphasize that the systems' quality is vital to comply with the services offered.

When the deployment of 3G-SHSs began, some organizations, such as the International Electrotechnical Commission (IEC), worked on quality assurance. The result was a series of documents for renewable hybrid systems dedicated to rural electrification, IEC 612579-5 [102]. Aligned to this, the international program Lighting Global [103] has published a standard named Solar Home System Kits Quality Standards [104] based on the IECs publications and considering its verification procedure. In February 2020, Lighting Global, the Collaborative Labeling and Appliance Standards Program (CLASP), and the Schatz Energy Research Center launched VeraSol, an evolved quality assurance program for modern off-grid solar solutions, providing product certifications that meet international standards [105], and will continue with the work of Lighting Global.

The quality assurance must guarantee that the technical conditions specified in the products are met under international standards that ensure the useful life and efficiency. However, it must also ensure that the products respond to the population's needs, achieving social acceptance [98]. Finally, it must protect the consumer in aspects such as transparency of information and compliance of companies' guarantees.

The products that meet the standard are listed on their website [106]; for October 2021, in the category solar energy kits, exist as 57 brands and 189 kits certified with different sizes and capabilities.

However, GOGLA (2020) indicates that out of 30.6 million SHSs products sold in 2018, only 7.6 million were affiliated companies' to GOGLA [24,107]. Along these lines, defining a standard similar to the Universal Technical Standard for Photovoltaic Systems 
but oriented to 3G-SHSs, with broad applicability, and setting up more laboratories and test centers, are a pending challenge.

\subsection{Operational Characterization of 3G-SHSs}

Adopting LED technology for lighting decreases the energy consumption, which adds to the increasing efficiency of loads such as flat-screen televisions, compact radios, and cell phones, making a less need for energy storage [94]. A lower electricity requirement (using very efficient loads) allows the use of smaller PV modules, facilitating transport and installation, and the weight reduction of 3G-SHSs. The interactions between the innovative components of 3G-SHSs are shown in Figure 16.

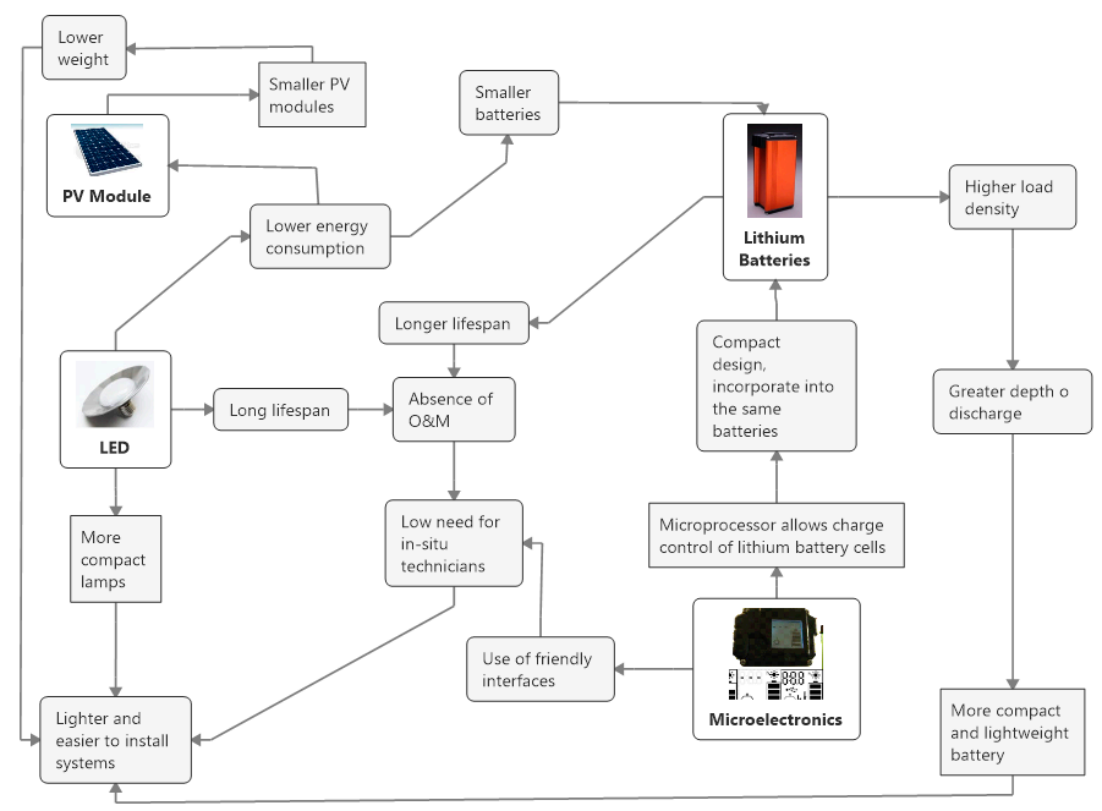

Figure 16. Inter-relationships identified between LED, microelectronics, and lithium batteries.

In the same line, the high charge density of lithium batteries, their large number of charge and discharge cycles, and their depth of discharge in regular use of almost $100 \%$, implies the use of smaller and more compact batteries [108,109], which additionally do not require periodic maintenance. However, lithium batteries' complexity of charge control would not have been possible to achieve in operational terms without microelectronics and microprocessors. Microprocessors and a high-resolution screen make it possible to use icons, symbols, and display information dynamically and easily to understand by the final user. Furthermore, the application of integrality concepts, modularity, and easy connections show a completely different functionality from 2G-SHSs.

Analyzing the operation of a 3G-SHS is possible to identify the following advantages:

- Smaller and more efficient systems.

- Lightweight systems: A 3G-SHS weighs $6 \mathrm{~kg}$ (a traditional SHS, weighs over $50 \mathrm{~kg}$ ), which results in easier transport logistics.

- Lower cost: The price of a system of this type is less than $50 \%$ of a conventional 2G-SHS (USD 900).

- Longer lifespan: The system's operational lifetime could be between 8 and 10 years with a lithium iron phosphate battery between 2500 to 3000 charge/discharge cycles (already available in the market) and LED lamps with 50,000 $\mathrm{h}$ of use.

- Minimal after-sales service: The low probability of failures makes that the systems not require operation and maintenance services by specialized technicians in situ and, rather, makes the user interact much more with the equipment.

- Self-installation by the user: An installation by specialized technicians is not necessary, and thus, the same end-user can do it with an adequate training process. 
Undoubtedly, it can be seen that the sum of radical and incremental innovations, in this case, have achieved a superior version of the product [110,111]. Therefore, it can be said that it is a new generation of SHSs. A 3G-SHS is not only more efficient, compact, lightweight, and cheap. It is also a friendly and intelligent system since the microprocessor allows, beyond the handling of information to the user, the consumption record and the possibility of interacting remotely with a suitable interface. Through the connection with cellular networks, it can operate microcredit or innovative payment systems known as Pay As You Go (PAYG) which, for certain contexts such as Sub-Saharan Africa, are rapidly expanding access to this technology $[112,113]$.

In LAC, the population without access to energy lives in regions without access to cell phone services and very high dispersion. The application of the PAYG business model is limited since it requires communication technologies as a condition [114]. However, the capabilities of 3G-SHSs to manage equipment access locks are used for initiatives such as the rent-to-own of Quetsol in Guatemala [115] and sales of equipment on credit in Bolivia [32]. In both cases, users pay their fees periodically, and the unlock is done manually and not online. With this solution, collection costs and risks are minimized.

Three aspects such as: The possibility of self-installation by the user, the absence of need for periodic maintenance of 3G-SHSs by technicians, and the long useful life of the components (lithium battery, LED lamps, and PV panel), reduce the need to provide Operation and Maintenance (O\&M) services with periodically home visits (as it is done with 2G-SHSs). As these, in situ services, are unnecessary, an important component of operating costs in the system's life cycle is minimized. However, it is necessary to change the logic of technicians visiting houses by having fixed technical assistance centers when the user takes his equipment for repair.

All these elements will impact on the actions in massive PV electrification projects since the 3G-SHSs allow optimizing investment resources, improving the technical and economic sustainability of access to energy and facilitating the logistics and implementation conditions of the projects, and, finally, it rethinks the traditional ways of executing photovoltaic electrification projects for homes.

Over the last 20 years, installations of SHS for rural households have grown in LAC. Reviewing the statistics available for the isolated photovoltaic capacity installed in rural homes in LAC and the number of people who use them [116], Figure 17 has been constructed, which shows the relationship between the installed power in the SHS for the period 2007-2017 by year, and also shows the presence of 2G-SHS and 3G-SHS.

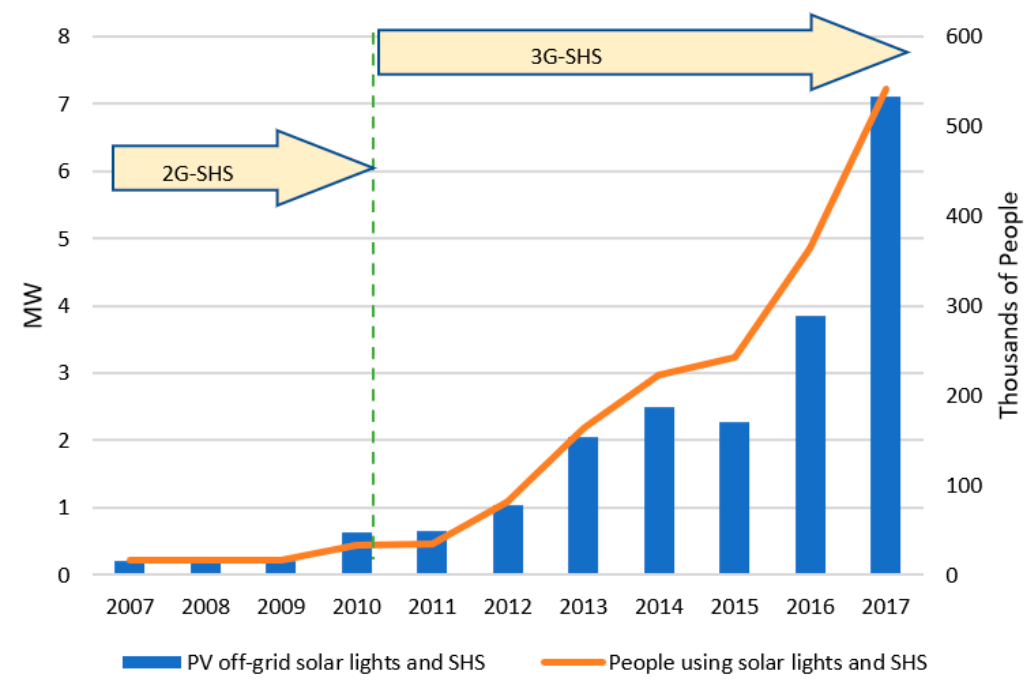

Figure 17. Installed capacity of photovoltaic (PV) off-grid in LAC 2007-2017. Elaborated with data of [116]. 


\section{Conclusions}

This research reviews the information from 1980 to date on PV rural electrification, showing that most of the people without access to electricity, especially in LAC, live in rural, isolated, and dispersed areas. In addition, the lack of electricity seriously limits the quality of life in terms of lighting, communication, and education services. For these populations, decentralized solutions based on renewable energy and specifically solar energy are a realistic option.

For supplying energy to isolated households, SHS is a widely used alternative throughout the world, with a success level that has been improving over time due to progressive technological innovations in different components of SHSs. When these sets of innovations become disruptive, they affect the SHS functionality and produce a new SHS version. In this review, three generations of SHSs have been clearly identified. During the transition time from one generation to another, the current generation tends to coexist with the improved version, generating hybrid versions with a short validity time.

The last technological innovations (LED lighting, lithium batteries, microelectronic control, and plug and play connection systems) integrated into the SHS are called 3GSHS, which have achieved technological safety and a long useful life in all components (about 10 years). The 3G-SHSs are easy to operate, require minimum maintenance, and have lower costs than the previous generations. With 3G-SHSs, operational issues such as transport and installation are no longer a barrier since the end-user can perform them. With minimal maintenance requirements, technicians do not need to visit users periodically, and after-sales service costs drop dramatically.

The 3G-SHSs allow overcoming the barriers of the traditional SHS: High initial investment, need of specialized technicians for installation and maintenance, high costs of battery replacement, and, particularly in LAC, logistics, transport, and execution are becoming more complex and expensive due to the dispersion of users and inaccessible areas. Moreover, the technological advances in 3G-SHSs allow new business models and institutional forms that manage the universal access to electricity to be developed. It is important to identify the experiences generated in a broad and accelerated manner in Sub-Saharan Africa and, considering LACs particularities, to select those that can be used successfully.

From the point of view of progress in universal access to energy, SDG 7, using the Multi Tiers framework, the 3G-SHS allows covering the Tier 1 and Tier 2 with clear advantages over 2G-SHS. Another important variable to consider is the technological advances of household appliances' increasing efficiency (TVs, fans, and refrigerators). In other words, less and less energy needs to obtain the same services. Disregarding these advances can lead to oversizing and unnecessary costs of SHSs.

Given the difficulties in promoting universal access in LAC and other regions of the world, 3G-SHSs are strategically a recommended solution to achieve this global goal.

Author Contributions: Conceptualization, M.H.F.-F., A.A.E.-A., and M.A.E.-A.; methodology, M.H.F.F., A.A.E.-A., and M.A.E.-A.; investigation, M.H.F.-F.; resources, M.H.F.-F., A.A.E.-A., and M.A.E.-A.; writing-original draft preparation, M.H.F.-F.; writing—review and editing, M.H.F.-F., A.A.E.-A., and M.A.E.-A.; supervision, M.A.E.-A. All authors have read and agreed to the published version of the manuscript.

Funding: This research was funded by ENERGETICA through the projects: The Microfranchises for Access to Clean Energy in Rural Areas, and Deploying New Solar Technologies for Isolated Rural Areas: Supporting their Adoption in the LAC Region.

Institutional Review Board Statement: Not applicable.

Informed Consent Statement: Not applicable.

Data Availability Statement: Data applied in this study is well-cited throughout the text, and no new data were created.

Conflicts of Interest: The authors declare no conflict of interest. 


\section{References}

1. United Nations United Nations Sustainable Development-17 Goals to Transform Our World. Available online: https://www.un. org/sustainabledevelopment/ (accessed on 24 July 2020).

2. World Bank. The Welfare Impact of Rural Electrification: A Reassessment of the Costs and Benefits; World Bank: Washington, DC, USA, 2008; ISBN 9780821373675.

3. Pearce, D.; Webb, M. Rural electrification in developing countries. Energy Policy 1987, 15, 329-338. [CrossRef]

4. Bambawale, M.J.; D'Agostino, A.L.; Sovacool, B.K. Realizing rural electrification in Southeast Asia: Lessons from Laos. Energy Sustain. Dev. 2011, 15, 41-48. [CrossRef]

5. Torero, M. The Impact of Rural Electrification: Challenges and Ways Forward. Rev. D'écon. Dév. 2015, 23, 49. [CrossRef]

6. Ayaburi, J.; Bazilian, M.; Kincer, J.; Moss, T. Measuring “Reasonably Reliable" access to electricity services. Electr. J. 2020, 33, 106828. [CrossRef]

7. IEA SDG7: Data and Projections. Available online: https://www.iea.org/reports/sdg7-data-and-projections/access-to-electricity (accessed on 23 February 2021).

8. Cook, P. Infrastructure, rural electrification and development. Energy Sustain. Dev. 2011, 15, 304-313. [CrossRef]

9. World Bank. WHO Tracking SDG 7: The Energy Progress Report; World Bank: Washington, DC, USA, 2020.

10. International Energy Agency (IEA). The Covid-19 Crisis is Reversing Progress on Energy Access in Africa; International Energy Agency: Paris, France, 2020.

11. Garcia, F.; Moreno, A.; Schushny, A. Analysis of the Impacts of the COVID-19 Pandemic on the Energy Sector in Latin America and the Caribbean; Government of Ecuador: Quito, Ecuador, 2020.

12. PERMER Tender Completed. Available online: https://permer.minem.gob.ar/licitacion/historico (accessed on 10 August 2020).

13. Chakravorty, U.; Emerick, K.; Ravago, M.-L. Lighting Up the Last Mile: The Benefits and Costs of Extending Electricity to the Rural Poor. SSRN Electron. J. 2016. [CrossRef]

14. Slough, T.; Urpelainen, J.; Yang, J. Light for all? Evaluating Brazil's rural electrification progress, 2000-2010. Energy Policy 2015, 86, 315-327. [CrossRef]

15. The World Bank Access to Electricity (\% of Population) Latin America \& Caribbean. Available online: https://data.worldbank. org/indicator/EG.ELC.ACCS.ZS?locations=ZJ\&name_desc=false (accessed on 24 February 2021).

16. Eras-Almeida, A.A.; Egido-Aguilera, M.A. What Is Still Necessary for Supporting the SDG7 in the Most Vulnerable Contexts? Sustainability 2020, 12, 7184. [CrossRef]

17. Banal-Estañol, A.; Calzada, J.; Jordana, J. How to achieve full electrification: Lessons from Latin America. Energy Policy 2017, 108, 55-69. [CrossRef]

18. Coviello, M.; Ruchansky, B. Advances in Sustainable Energy Issues in Latin America and the Caribbean. In Results of the Global Monitoring Framework. Report 2017; World Energy Council: Santiago, Chile, 2017.

19. Jiménez, R. Development Effects of Rural Electrification; Inter-American Development Bank: New York, NY, USA, 2017.

20. Jimenez, R. Barriers to electrification in Latin America: Income, location, and economic development. Energy Strat. Rev. 2017, 15, 9-18. [CrossRef]

21. Biermann, E.; Haars, K.; Müller, W. Solar Home Systems-An Energy Supply Option for Rural Areas. In Advances in Solar Energy Technology; Elsevier BV: Amsterdam, The Netherlands, 1988; pp. 318-322.

22. Nieuwenhout, F.D.J.; van Dijk, A.; Lasschuit, P.E.; van Roekel, G.; van Dijk, V.A.P.; Hirsch, D.; Arriaza, H.; Hankins, M.; Sharma, B.D.; Wade, H. Experience with solar home systems in developing countries: A review. Prog. Photovolt. Res. Appl. 2001, 9, 455-474. [CrossRef]

23. Chaurey, A.; Kandpal, T.C. Assessment and evaluation of PV based decentralized rural electrification: An overview. Renew. Sustain. Energy Rev. 2010, 14, 2266-2278. [CrossRef]

24. Lighting Global GOGLA ESMAP Off-Grid Solar Market Trends Report 2020; Market Intelligence \& Trends: Washington, DC, USA, 2020.

25. Van Els, R.H.; Vianna, J.N.D.S.; Brasil, A.C.P. The Brazilian experience of rural electrification in the Amazon with decentralized generation-The need to change the paradigm from electrification to development. Renew. Sustain. Energy Rev. 2012, 16, 1450-1461. [CrossRef]

26. Ministry of Energy and Mines Brazil Rural Electrification Program. Available online: https://www.mme.gov.br/luzparatodos/ Asp/o_programa.asp (accessed on 10 August 2020).

27. Valer, L.R.; Manito, A.R.; Ribeiro, T.B.S.; Zilles, R.; Pinho, J.T. Issues in PV systems applied to rural electrification in Brazil. Renew. Sustain. Energy Rev. 2017, 78, 1033-1043. [CrossRef]

28. World Bank. International Bank for Reconstruction and Development Project Appraisal Document on a Proposed Loan in the Amount of US\$200 Million to the Argentine Republic for a Renewable Energy for Rural Areas Project; World Bank: Washington, DC, USA, 2015.

29. The World Bank. Implementation Completion and Results Report IDA-54540 on a Credit in the Amount of SDR32.4 Million (US\$ 50 Million Equivalent) to the Plurinational State of Bolivia for the Access and Renewable Energy Project October 28; World Bank: Washington, DC, USA, 2019.

30. INE. Results, National Population and Housing Census. 2012. Available online: http://datos.ine.gob.bo/binbol/RpWebEngine. exe/Portal?BASE=CPV2012COM\&lang=ESP (accessed on 9 November 2020). 
31. Ministry of Hydrocarbons and Energy International. Public Bidding No. GPOBA- LPI 01/2010 CUCE: 10-0078-00-198883-1-1; Ministry of Hydrocarbons and Energy International: La Paz, Bolivia, 2010.

32. Inter American Development Bank. BO-L1127: Development of Microfranchises for Access to Clean Energy in Rural Areas. Available online: https:/ / www.iadb.org/en/project/BO-L1127 (accessed on 12 November 2020).

33. Peters, J.; Sievert, M.; Toman, M.A. Rural electrification through mini-grids: Challenges ahead. Energy Policy 2019, 132, 27-31. [CrossRef]

34. Alam, M.; Bhattacharyya, S. Decentralized Renewable Hybrid Mini-Grids for Sustainable Electrification of the Off-Grid Coastal Areas of Bangladesh. Energies 2016, 9, 268. [CrossRef]

35. Balderrama, S.; Canedo, W.; Fernandez, M.; Lemort, V.; Quoilin, S. Techno-economic optimization of isolate microgrids including PV and Li-Ion Batteries in the Bolivian context. In Proceedings of the ECOS 2016 29th International Conference on Efficiency, Cost, Optimisation, Simulation and Environmental Impact of Energy Systems, Rome, Italy, 25-29 May 2016.

36. Díaz, P.; Pena, R.; Munoz, J.; Arias, C.; Sandoval, D. Field analysis of solar PV-based collective systems for rural electrification. Energy 2011, 36, 2509-2516. [CrossRef]

37. Martinot, E.; Cabraal, A.; Mathur, S. World Bank/GEF solar home system projects: Experiences and lessons learned 1993-2000. Renew. Sustain. Energy Rev. 2001, 5, 39-57. [CrossRef]

38. Van Der Vleuten, F.; Stam, N.; van der Plas, R. Putting solar home system programmes into perspective: What lessons are relevant? Energy Policy 2007, 35, 1439-1451. [CrossRef]

39. Rahman, S.M.; Ahmad, M.M. Solar Home System (SHS) in rural Bangladesh: Ornamentation or fact of development? Energy Policy 2013, 63, 348-354. [CrossRef]

40. Sharif, I.; Mithila, M. Rural Electrification using PV: The Success Story of Bangladesh. Energy Procedia 2013, 33, 343-354. [CrossRef]

41. Arraiz, I.; Calero, C. From Candles to Light: The Impact of Rural Electrification; Inter-American Development Bank: New York, NY, USA, 2015.

42. Horn, M. Solar Photovoltaics for Sustainable Rural Electrification in Developing Countries; The Experiences in Peru. In Proceedings of the ISES Solar World Congress, Göteborg, Sweden, 14-19 June 2003.

43. Chowdhury, S.A.; Mourshed, M. Off-grid electrification with solar home systems: An appraisal of the quality of components. Renew. Energy 2016, 97, 585-598. [CrossRef]

44. Egido, M.A.; Vega, P.; Horn, M.J. Field Evaluation of a PV Rural Electrification Project in a Titicaca Lake Island. In Proceedings of the 19th European Photovoltaic Solar Energy Conference, Paris, France, 7-11 June 2004.

45. Jacobson, A.; Kammen, D.M. Engineering, institutions, and the public interest: Evaluating product quality in the Kenyan solar photovoltaics industry. Energy Policy 2007, 35, 2960-2968. [CrossRef]

46. Komatsu, S.; Kaneko, S.; Ghosh, P.P.; Morinaga, A. Determinants of user satisfaction with solar home systems in rural Bangladesh. Energy 2013, 61, 52-58. [CrossRef]

47. ESMAP Global Lighting Services for the Poor Phase II: Test Marketing of Small "Solar" Batteries for Rural Electrification Purposes; World Bank: Washington, DC, USA, 1999.

48. Djamin, M.; Dasuki, A.S.; Lubis, A.Y. Performance Evaluation of Solar Home Systems after More Than Ten Years of Operation in Indonesia. In World Renewable Energy Congress VI; Elsevier BV: Amsterdam, The Netherlands, 2000; pp. $2022-2025$.

49. Gustavsson, M.; Mtonga, D. Lead-acid battery capacity in solar home systems-Field tests and experiences in Lundazi, Zambia. Sol. Energy 2005, 79, 551-558. [CrossRef]

50. Díaz, P.; Egido, M.Á.; Nieuwenhout, F. Dependability analysis of stand-alone photovoltaic systems. Prog. Photovolt. Res. Appl. 2007, 15, 245-264. [CrossRef]

51. Huacuz, J.M.; Flores, R.; Agredano, J.; Munguia, G. Field performance of lead-acid batteries in photovoltaic rural electrification kits. Sol. Energy 1995, 55, 287-299. [CrossRef]

52. Mondal, A.H. Economic viability of solar home systems: Case study of Bangladesh. Renew. Energy 2010, 35, 1125-1129. [CrossRef]

53. Kabir, E.; Kim, K.-H.; Szulejko, J.E. Social Impacts of Solar Home Systems in Rural Areas: A Case Study in Bangladesh. Energies 2017, 10, 1615. [CrossRef]

54. Foley, G. Photovoltaic Applications in Rural Areas of the Developing World; ESMAP Technical Paper 009; World Bank: Washington, DC, USA, 2000.

55. Lambert, D.; Holland, R.; Crawley, K. Appropriate battery technology for a new, rechargeable, micro-solar lantern. J. Power Sources 2000, 88, 108-114. [CrossRef]

56. Nygaard, I.; Hansen, U.E.; Larsen, T.H. The Emerging Market for Pico-Scale Solar PV Systems in Sub-Saharan Africa: From Donorsupported Niches Toward Market-Based Rural Electrification; UNEP DTU Partnership: Oslo, Norway, 2016.

57. Hirmer, S.; Cruickshank, H. Making the deployment of pico-PV more sustainable along the value chain. Renew. Sustain. Energy Rev. 2014, 30, 401-411. [CrossRef]

58. Reiche, K. ESMAP-SME: Final Report on Bolivia PicoPV. No. 69439; World Bank: Washington, DC, USA, 2009.

59. EnDev Bolivia Studies with Pico PV Systems in Bolivia; Ministry of Hydrocarbons and Energy International: La Paz, Bolivia, 2010.

60. Verastegui, A. Amaray_Energy and Development for Rural Areas; Springer: Lima, Peru, 2012; p. 27.

61. Rolland, S.; Glania, G. Rural Electrification with Renewable Energy: Technologies, Quality Standards and Business Models; Alliance for Rural Electification: Brussels, Belgium, 2011.

62. Keane, J. Pico-Solar Electric Systems: The Earthscan Expert Guide to the Technolgy and Emerging Market; CRC Press: New York, NY, USA, 2014; ISBN 9780415823593. 
63. Alstone, P.; Jacobson, A. LED advances accelerate universal access to electric lighting. Comptes Rendus Phys. 2018, 19, 146-158. [CrossRef]

64. Lysen, E. Pico Solar PV Systems for Remote Homes-A New Generation of Small PV Systems for Lighting and Communication; International Energy Agency: Paris, France, 2013.

65. Ruud, K.; Olivier, L.O.; Deger, S.; Jeffrey, S.; Salvatore, V.; Dolf, G.; Kempener, R.; Lavagne, O.; Saygin, D.; Skeer, J.; et al. Off-Grid Renewable Energy Systems: Status and Methodological Issues; The International Renewable Energy Agency (IRENA): New York, NY, USA, 2015; p. 29.

66. Bardouille, P.; Avato, P.; Levin, J.; Pantelias, A.; Engelmann-Pilger, H. From Gap to Opportunity: Business Models for Scaling Up Energy Access; ISSUU: Washington, DC, USA, 2012.

67. GOGLA. Lighting Global Global Off-Grid Solar Market Report Semi-Annual Sales and Impact Data. July-December 2017; GOGLA: Utrecht, The Netherlands, 2017.

68. Bazilian, M.; Onyeji, I.; Liebreich, M.; MacGill, I.; Chase, J.; Shah, J.; Gielen, D.; Arent, D.; Landfear, D.; Zhengrong, S. Reconsidering the economics of photovoltaic power. Renew. Energy 2013, 53, 329-338. [CrossRef]

69. Schaube, P.; Ortiz, W.; Recalde, M. Status and future dynamics of decentralised renewable energy niche building processes in Argentina. Energy Res. Soc. Sci. 2018, 35, 57-67. [CrossRef]

70. Van den Akker, J.H.A. Final Evaluation Rural Electrification Based on Photovoltaic Energy in the Peru—Project PER/98/G31; ASCENDIS: Amsterdam, The Netherlands, 2008.

71. World Bank Peru. Electrification Project in Rural Areas 747397. Available online: https:/ / projects.worldbank.org/en/projectsoperations / project-detail/P090110 (accessed on 30 October 2020).

72. Bhatia, M.; Angelou, N. Beyond Connections. Beyond Connect. 2015. [CrossRef]

73. Rosenblum, L.; Bifano, W.J.; Hein, G.F.; Ratajczak, A.F. Photovoltaic Power Systems for Rural Areas of Developing Countries. Nat. Resour. Forum 1980, 4, 5-18. [CrossRef]

74. Van Campen, B.; Guidi, D.; Best, G. Solar Photovoltaics for Sustainable Agriculture and Rural Development; FAO: Roma, Italy, 2000.

75. Alazraki, R.; Haselip, J. Assessing the uptake of small-scale photovoltaic electricity production in Argentina: The PERMER project. J. Clean. Prod. 2007, 15, 131-142. [CrossRef]

76. Aguilera, J.; Lorenzo, E. Rural photovoltaic electrification programme on the Bolivian high plateau. Prog. Photovolt. Res. Appl. 1996, 4, 77-84. [CrossRef]

77. Morning Star Morning Star History. Available online: https://www.morningstarcorp.com/company/history/ (accessed on 6 June 2019).

78. Steca Steca. Solar Charger Controllers. Available online: https://www.steca.com/index.php?Solar_charge_controllers_for_solar_ home_systems (accessed on 22 September 2020).

79. Bates, J.; Wilshaw, A. Stand-Alone PV Systems in Developing Countries; International Energy Agency: Paris France, 1999.

80. IES-UPM GENEC WIP ESTI-JRC Universal Technical Standard for Solar Home Systems Thermie B: SUP-995-96; International Energy Agency: Paris, France, 1998.

81. IBNORCA Bolivian Standard NB 1056. Installation of Photovoltaic Systems Up to 5000 Wp Power-Requirements; Ministry of Hydrocarbons and Energy International: La Paz, Bolivia, 2008.

82. Wilshaw, A.R.; Bates, J.R.; Oldach, R. Review of Standards and Quality Assurance Schemes for PV Systems. In Proceedings of the 16th European PV Solar Energy Conference and Exhibition, Glasgow, UK, 1-5 May 2000.

83. Morante, F.; Zilles, R. Electric consumption in SHSs in rural communities of Brazil and Peru and recommendations for sizing. Prog. Photovolt. Res. Appl. 2008, 16, 171-179. [CrossRef]

84. Hiranvarodom, S. PV Systems Installed at a Thai University for PV Development: Real Lessons Learnt. In Proceedings of the 2006 IEEE 4th World Conference on Photovoltaic Energy Conference, Dallas, TX, USA, 7-12 May 2006; IEEE: Piscataway, NJ, USA, 2006; Volume 2, pp. 2407-2410.

85. Reiche, K.; Rysankova, D.; Goldmark, S. Output-Based Aid in Bolivia. Balanced Tender Design for Sustainable Energy Access in Difficult Markets; GPOBA: Washington, DC, USA, 2007.

86. ENERGETICA. Report: Dissemination Materials of the IDTR Project; ENERGETICA: Cochabamba, Bolivia, 2006.

87. OSINERGMIN Bases for the Auction of Electricity Supply with Renewable Energy Resources in Areas Not Connected to the Grid; International Energy Agency: Lima, Peru, 2013.

88. Schmukler, M.; Garrido, S. Rural electrification in Argentina. Socio-technical adaptation of the PERMER program in the Province of Jujuy. ASADES 2016, 4, 12.71-12.81.

89. Reiche, K.; Gruner, R.; Attigah, B.; Hellpap, C.; Bruderle, A. What Difference Can a PicoPV System Make? Early Findings on Small Photovoltaic Systems-An Emerging Low-Cost Energy Technology for Developing Countries; KTH Industrial Engineering: Eschborn, Germany, 2010.

90. Feron, S. Sustainability of Off-Grid Photovoltaic Systems for Rural Electrification in Developing Countries: A Review. Sustainability 2016, 8, 1326. [CrossRef]

91. IEA. Defining energy access: 2020 methodology. Energy Access. Achiev. Mod. 2020, 16, 260-271.

92. Reiche, K.; Covarrubias, A.; Martinot, E. Expanding electricity access to remote areas: Off-grid rural electrification in developing countries. Fuel 2000, 1, 1-4.

93. Pode, R. Financing LED solar home systems in developing countries. Renew. Sustain. Energy Rev. 2013, 25, 596-629. [CrossRef] 
94. Phadke, A.A.; Jacobson, A.; Park, W.Y.; Lee, G.R.; Alstone, P.; Khare, A. Powering a Home with Just 25 Watts of Solar PV. In Super-Efficient Appliances Can Enable Expanded Off-Grid Energy Service Using Small Solar Power Systems; Berkeley National Laboratoty: Barkeley, CA, USA, 2015.

95. Lai, E.; Muir, S.; Ruff, Y.E. Off-grid appliance performance testing: Results and trends for early-stage market development. Energy Effic. 2019, 13, 323-347. [CrossRef]

96. Boucher, L.; Hassan, A.; Lai, E.; Macdonald, R.; Maina, M.; Spiak, M.; Jamieson, W.; Tod, A. 2021 Appliance Data Trends. Efficiency for Access Coalition. 2021. Available online: https:/ / efficiencyforaccess.org/publications/2021-appliance-data-trends (accessed on 6 March 2021).

97. Ottavianelli, E.; Cadena, C. Actions for Access to Energy by Rural People with the Inclusion of 3rd Generation PV Solar Systems and other Equipment. In Proceedings of the Minutes of the XXXIX Working Meeting of the Association Argentina of Renewable Energy and Environment, Buenos Aires, Argentina, 25-28 October 2016; pp. 12.61-12.69.

98. Eras-Almeida, A.A.; Fernández, M.; Eisman, J.; Martín, J.G.; Caamaño, E.; Egido-Aguilera, M.A. Lessons Learned from Rural Electrification Experiences with Third Generation Solar Home Systems in Latin America: Case Studies in Peru, Mexico, and Bolivia. Sustainability 2019, 11, 7139. [CrossRef]

99. Krieger, E.M.; Cannarella, J.; Arnold, C.B. A comparison of lead-acid and lithium-based battery behavior and capacity fade in off-grid renewable charging applications. Energy 2013, 60, 492-500. [CrossRef]

100. Fernandez, M. Technological and management innovations to achieve universal access. In Off-Grid Energy for rural Development in Latin America and the Caribbean Closing Workshop; Smart Villages: Panama City, Panama, 2017; pp. 25-26.

101. Alstone, P.; Lai, P.; Mills, E.; Jacobson, A. High Life Cycle Efficacy Explains Fast Energy Payback for Improved Off-Grid Lighting Systems. J. Ind. Ecol. 2014, 18, 722-733. [CrossRef]

102. IEC Webstore. International Electrotechnical Commission. Available online: https://webstore.iec.ch/publication/25275 (accessed on 14 July 2020).

103. World Bank Group Lighting Global. Available online: https://www.lightingglobal.org/ (accessed on 10 July 2020).

104. Lighting Global Solar Home System Kit Quality Standards. Available online: https://www.lightingglobal.org/wp-content/ uploads/2018/09/SHS_MQS_v2_4-20180901.pdf (accessed on 27 October 2020).

105. VeraSol Quality Assurance for Modern Off-Grid Solar Solutions. Available online: https:/ /verasol.org/ (accessed on 25 February 2021).

106. Lighting Global Products. Available online: https://www.lightingglobal.org/products/ (accessed on 1 October 2020).

107. Balls, J.N. Low-cost, adaptable solutions sell: Re-thinking off-grid solar diffusion at the bottom of the pyramid in India. Energy Res. Soc. Sci. 2020, 70, 101811. [CrossRef]

108. Tarascon, J.-M.; Armand, M. Issues and challenges facing rechargeable lithium batteries. Nat. Cell Biol. 2001, $414,359-367$. [CrossRef] [PubMed]

109. Scrosati, B.; Garche, J. Lithium batteries: Status, prospects and future. J. Power Sources 2010, 195, 2419-2430. [CrossRef]

110. Perez, C. Technological revolutions and techno-economic paradigms. Camb. J. Econ. 2009, 34, 185-202. [CrossRef]

111. Slater, S.F.; Mohr, J.J.; Sengupta, S. Radical Product Innovation Capability: Literature Review, Synthesis, and Illustrative Research Propositions. J. Prod. Innov. Manag. 2013, 31, 552-566. [CrossRef]

112. Rolffs, P.; Ockwell, D.; Byrne, R. Beyond technology and finance: Pay-as-you-go sustainable energy access and theories of social change. Environ. Plan. A Econ. Space 2015, 47, 2609-2627. [CrossRef]

113. Yadav, P.; Heynen, A.P.; Palit, D. Pay-As-You-Go financing: A model for viable and widespread deployment of solar home systems in rural India. Energy Sustain. Dev. 2019, 48, 139-153. [CrossRef]

114. IRENA. Innovation Landscape Brief: Pay-As-You-Go Models; International Renewable Energy Agency: Abu Dhabi, United Arab Emirates, 2020.

115. Energypedia Fee-For-Service or Pay-As-You-Go Concepts for Photovoltaic Systems. Available online: https:/ / energypedia.info/ wiki/Fee-For-Service_or_Pay-As-You-Go_Concepts_for_Photovoltaic_Systems\#Latin_America (accessed on 25 February 2021).

116. Whiteman, A.; Usmanova, S. Off-Grid Renewable Energy Statistics 2019; International Renewable Energy Agency: Abu Dhabi, United Arab Emirates, 2019. 